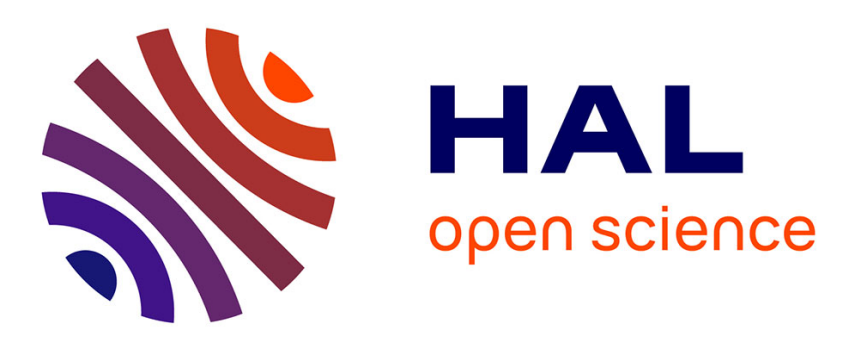

\title{
Hf-Nd input flux in the Izu-Mariana subduction zone and recycling of subducted material in the mantle.
} Catherine Chauvel, Jean-Christophe Marini, Terry Plank, John N. Ludden

\section{To cite this version:}

Catherine Chauvel, Jean-Christophe Marini, Terry Plank, John N. Ludden. Hf-Nd input flux in the Izu-Mariana subduction zone and recycling of subducted material in the mantle.. Geochemistry, Geophysics, Geosystems, 2009, 10, pp.Q01001. 10.1029/2008GC002101 . insu-00410714

\section{HAL Id: insu-00410714 https://hal-insu.archives-ouvertes.fr/insu-00410714}

Submitted on 11 Mar 2021

HAL is a multi-disciplinary open access archive for the deposit and dissemination of scientific research documents, whether they are published or not. The documents may come from teaching and research institutions in France or abroad, or from public or private research centers.
L'archive ouverte pluridisciplinaire HAL, est destinée au dépôt et à la diffusion de documents scientifiques de niveau recherche, publiés ou non, émanant des établissements d'enseignement et de recherche français ou étrangers, des laboratoires publics ou privés. 


\title{
Hf-Nd input flux in the Izu-Mariana subduction zone and recycling of subducted material in the mantle
}

\author{
Catherine Chauvel and Jean-Christophe Marini \\ LGCA, CNRS, Université Joseph Fourier, BP 53, F-38041 Grenoble CEDEX 09, France \\ (catherine.chauvel@ujf-grenoble.fr)
}

Terry Plank

Department of Earth Sciences, Boston University, 685 Commonwealth Avenue, Boston, Massachusetts 02215, USA

Now at Lamont Doherty Earth Observatory and Department of Earth and Environmental Sciences, Columbia

University, P. O. Box 1000, Palisades, New York 10964, USA (tplank@ldeo.columbia.edu)

\author{
John N. Ludden \\ British Geological Survey, Kingsley Dunham Centre, Keyworth, Nottingham NG12 5GG, UK (jludden@bgs.ac.uk)
}

[1] In subduction zones, two major mass fluxes compete: the input flux of altered oceanic crust and sediments subducted into the mantle and the output flux of magma that forms the volcanic arc. While the composition and the amount of material erupted along volcanic arcs are relatively well known, the chemical and isotopic composition of the subducted material (altered oceanic crust and sediments) is poorly constrained and is an important factor in the mass balance calculation. Ocean Drilling Program Leg 185 in the Western Pacific used systematic sampling of the altered basaltic basement and sediment pile and the creation of composite mixtures to quantify the total chemical flux subducted at the Izu-Mariana margin. Here, we report $\mathrm{Hf}$ and $\mathrm{Nd}$ isotopic compositions of materials recovered from this Leg. The $\mathrm{Hf}$ and $\mathrm{Nd}$ isotopic compositions of altered basalts from Hole $801 \mathrm{C}$ are indistinguishable from those of recent unaltered Pacific mid-ocean ridge basalt, suggesting that hydrothermal alteration had no effect on either isotopic systems. The complete Site 1149 sedimentary pile has a weighted average $\varepsilon_{\mathrm{Nd}}$ of -5.9 and $\varepsilon_{\mathrm{Hf}}$ of +4.4 , values similar to those of Fe-Mn crusts and nodules. Therefore, the $\mathrm{Hf}$ and $\mathrm{Nd}$ isotopic compositions of the sediments collected at Site 1149 indicate minimal contributions from continental detrital material to the rare earth elements and high field strength elements. However, the Hf isotopic budget of the oldest sediments is more influenced by continental material than the younger sediments, despite the large distances to continental masses $130 \mathrm{Ma}$ ago. In the Izu subduction zone, we calculate a sedimentary input of less than about $2 \%$ in the volcanic lava source. In contrast, at least $85 \%$ of the sedimentary $\mathrm{Nd}$ and $\mathrm{Hf}$ are recycled into the mantle to affect its general composition. Assuming that sediments have been recycled in a similar manner into the mantle for millions of years, large chemical heterogeneities must be produced in the mantle. In addition, the depletion of the mantle due to the extraction of continental crust must be partly counterbalanced by the injection of vast quantities of enriched sedimentary material.

Components: 12,949 words, 11 figures, 5 tables.

Keywords: isotopic geochemistry; oceanic sediments; island arc; Leg 185; Izu-Bonin Mariana; mantle recycling.

Index Terms: 1031 Geochemistry: Subduction zone processes (3060, 3613, 8170, 8413); 1030 Geochemistry: Geochemical cycles (0330); 1040 Geochemistry: Radiogenic isotope geochemistry. 
Received 17 May 2008; Revised 28 October 2008; Accepted 31 October 2008; Published 3 January 2009.

Chauvel, C., J.-C. Marini, T. Plank, and J. N. Ludden (2009), Hf-Nd input flux in the Izu-Mariana subduction zone and recycling of subducted material in the mantle, Geochem. Geophys. Geosyst., 10, Q01001, doi:10.1029/2008GC002101.

\section{Introduction}

[2] Subduction zones are the principal sites for exchange between the mantle and surficial geochemical reservoirs: the crust, ocean, and atmosphere. Magmas from subduction zones contribute to crustal growth and deliver volatile elements to the atmosphere. In return, the mantle is fertilized by subduction of altered oceanic crust and sediments containing elements derived from the continental crust and seawater [Armstrong, 1968, 1991; VonHuene and Scholl, 1991, 1993; Plank and Langmuir, 1998].

[3] Quantifying fluxes between material entering the subduction zone and volcanic outputs requires, on one hand, an accurate estimate of the chemical and isotopic composition of arc magmas and, on the other hand, a precise evaluation of the chemical and isotopic composition of subducted materials. Such evaluations have been made on a global scale by Plank and Langmuir [1998], who calculated average compositions for sediments subducted under various arcs as well as a global sediment composition called GLOSS. However, no complete section of basaltic crust and overlying sediments had ever been studied for its complete trace element and isotopic compositions. The primary scientific objective of Ocean Drilling Program (ODP) Leg 185, which was drilled in 1999 in the western Pacific, outboard of the Izu-Bonin-Mariana arc, was to sample and characterize a complete section of altered basaltic crust and overlying sedimentary pile [Plank et al., 2000]. Altered basaltic crust was drilled at Hole $801 \mathrm{C}$, east of the Mariana arc, and the sedimentary pile and basaltic basement were sampled at Site 1149 in front of the Izu arc. As part of this joint international effort, we analyzed $\mathrm{Nd}$ and $\mathrm{Hf}$ isotopes of basaltic samples from Hole $801 \mathrm{C}$ and sediments collected at Site 1149 while other teams concentrated their efforts on the mobility of trace elements in the basaltic basement [Kelley et al., 2003; Reisberg et al., 2008], on the $\mathrm{Sr}, \mathrm{Nd}, \mathrm{Pb}$ isotopic systematics of both sediments and basalts [Hauff et al., 2003], or on the trace element budget of the entire sedimentary pile [Plank et al., 2007]. Comparing the $\mathrm{Nd}$ and $\mathrm{Hf}$ isotopic compositions of the old altered basaltic crust with those of fresh Pacific mid-ocean ridge basalt (MORB) should provide constraints on the behavior of rare earth elements (REE) and high field strength elements (HFSE) during alteration of oceanic crust. These data will also provide a composition for oceanic crust recycled into the mantle. In addition, $\mathrm{Nd}$ and $\mathrm{Hf}$ isotopic compositions measured on the Site 1149 sediments provide constraints on the origin of REE and HFSE in sediments deposited in ocean basins and can be used to evaluate the average composition of downgoing sedimentary material in intraoceanic subduction zones. Our sediment results may also be compared to the pioneering $\mathrm{Hf}$ isotopic work on sediments from the western Pacific area of Woodhead [1989] and Pearce et al. [1999].

[4] Our work constrains the composition of the subducted materials regionally, and can be used to understand the genesis of the Izu-Mariana arc lavas. Western Pacific arcs have been exceptionally well studied, particularly for $\mathrm{Nd}$ and $\mathrm{Hf}$ isotopes [White and Patchett, 1984; Woodhead, 1989; Elliott et al., 1997; Pearce et al., 1999; Woodhead et al., 2001; Tollstrup and Gill, 2005; Wade et al., 2005; Stern et al., 2006]. In spite of this, there are no good estimates of the Nd-Hf input flux to these arc systems. More generally, such data on a complete section of subducted material provides an estimate of the flux of chemical elements recycled into the mantle and can help in understanding the long-term evolution of the composition of the mantle as a result of the balance between melt extraction through volcanic activities and recycling of basaltic crust and overlying sediments in subduction zones.

\section{Sample Selection}

[5] We focused our study on two different sets of samples: the first set is the suite of composite samples of basalts prepared by Kelley et al. [2003] to characterize the basaltic crust entering the subduction zone and sampled at ODP Site 801C (see Figure 1). This is the oldest crust formed at fast spreading rates and so is the reference basement section for much of the subducting western Pacific oceanic crust [Ludden et al., 2006]. The second set 


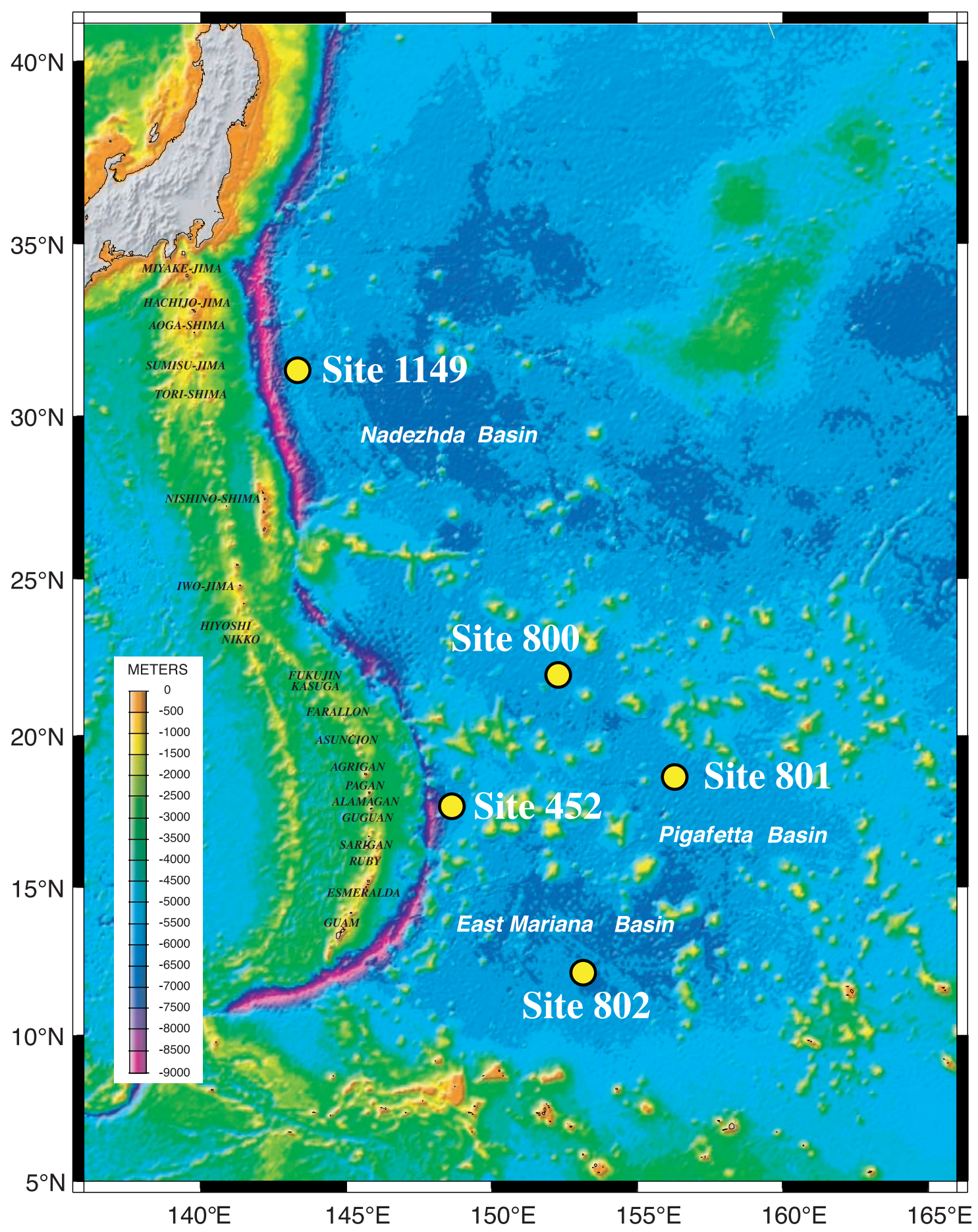

Figure 1. Map of the Western Pacific region with locations of Ocean Drilling Program (ODP) Sites 800, 801, 802, 1149, and DSDP Site 452 (modified from Plank et al. [2000]).

is a selection of sediment samples from ODP Site 1149 which represent the sedimentary cover overlying the oceanic crust (Figure 1). This site reflects all the major types of pelagic sedimentation found in the western Pacific, including chert, clay, and carbonate lithologies [Plank et al., 2007]. Samples were selected to cover the entire variability of the basaltic and sedimentary compositions along the cores and once weight averaged, they should represent the average composition of the old Pacific plate that enters 


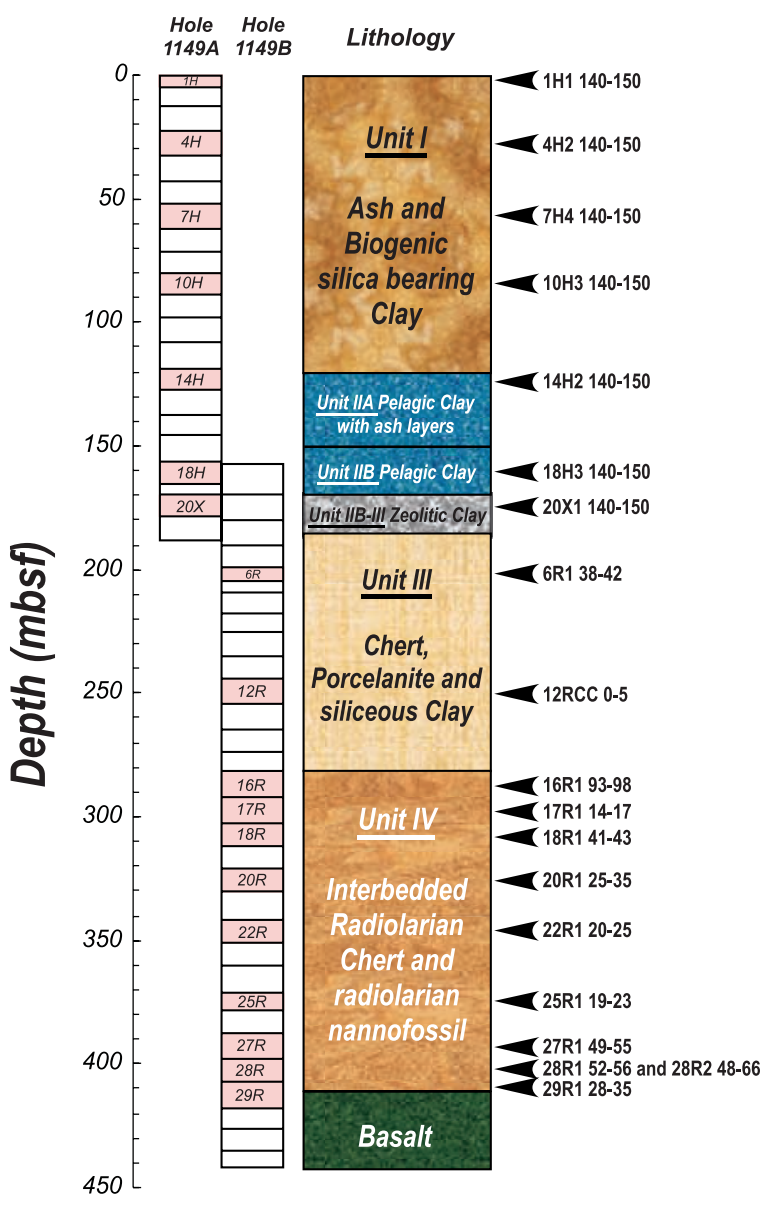

Figure 2. Lithostratigraphic column of Site 1149 with locations of samples analyzed for $\mathrm{Hf}$ and $\mathrm{Nd}$ isotopes. The transition between subunit IIB and unit III consists of zeolitic clays extremely enriched in REE relative to other Site 1149 sediments [Plank et al., 2007]. They have been considered as a distinct unit in this study.

subduction zones along a large sector of the western Pacific convergent margin.

\subsection{Basaltic Basement Drilled at ODP Site 801C}

[6] Hole $801 \mathrm{C}\left(18^{\circ} 38.5^{\prime} \mathrm{N}, 156^{\circ} 21.6^{\prime} \mathrm{E}\right)$ is located in the Pigafetta Basin (Figure 1), $950 \mathrm{~km}$ east of the Mariana trench. This hole was first drilled in 1989 during ODP Leg 129 [Lancelot et al., 1990]. In 1999 during ODP Leg 185, the hole was deepened to collect a more complete section of the altered oceanic crust [Plank et al., 2000]. A total thickness of $474 \mathrm{~m}$ was sampled and divided into eight major sequences based on petrological, mineralogical, and geochemical characteristics. The uppermost sequence consists of alkalic basalts and dolerites (about $20 \mathrm{~m}$ thick) while lower sequences are typical MORB with tholeiitic composition including massive flows or pillows associated with breccias, volcanoclastic material, and silicic hydrothermal deposits [Plank et al., 2000; Barr et al., 2002; Fisk and Kelley, 2002]. The upper alkalic basalts have an Ar-Ar age of $157 \mathrm{Ma}$ and the underlying MORB have ages ranging from 162 to $171 \mathrm{Ma}$ [Pringle, 1992; Koppers et al., 2003a]. Most basaltic materials from hole $801 \mathrm{C}$ are altered by low temperature hydrothermal fluids and interaction with low-temperature seawater, and the material varies from highly altered interpillow materials to better preserved massive flows. Some completely unaltered volcanic glasses also exist [Alt et al., 1992; Plank et al., 2000; Fisk and Kelley, 2002; Talbi and Honnorez, 2003].

[7] A set of composite samples was prepared by mixing powders of the various lithologies (massive flows, pillows, breccias, volcanoclastic materials, and hydrothermal deposits) according to their respective proportions in the hole. The procedure followed for sample preparation, as given by Kelley et al. [2003] led to the preparation of 13 composites representing the flows and pillows units, the breccias and volcanoclastic sediments. A global composite representative of the entire basaltic column was also prepared. Major and trace element compositions of these composites were measured by Kelley et al. [2003], stable isotopes have been published by Alt [2003], and Re-Os results were reported by Reisberg et al. [2008]. Our $\mathrm{Hf}$ and $\mathrm{Nd}$ isotopic compositions were obtained on the same composite samples.

\subsection{Sedimentary Pile Drilled at ODP Site 1149}

[8] The sedimentary cover subducted at the Mariana trench has been drilled and sampled during several DSDP and ODP campaigns (especially during the ODP Leg 129) and is one of the best studied sedimentary piles on a subducting oceanic plate [Plank and Langmuir, 1998]. In contrast, the sedimentary pile subducted in the Izu-Bonin region, north of the Mariana arc, was largely unknown and was therefore drilled at Site 1149 during ODP leg $185\left(31^{\circ} 20.1^{\prime} \mathrm{N}, 143^{\circ} 21.8^{\prime} \mathrm{E}\right.$; see Figure 1).

[9] In the Izu-Bonin region the sediments covering the Pacific crust have a thickness of about $410 \mathrm{~m}$ and include several lithological units (Figure 2):

[10] 1. Unit I, at the top of the sediment pile, has a thickness of about $118 \mathrm{~m}$. It consists of a mixture 
of clay minerals, siliceous planktonic microfossils (essentially diatoms and radiolarians), and volcanic ash. Paleomagnetic data indicate an age from late Miocene (about 6.5 Ma) to late Pleistocene (younger than $0.2 \mathrm{Ma})$.

[11] 2. Unit II (including subunits IIA and IIB) has a thickness of about $62 \mathrm{~m}$ and consists almost exclusively of pelagic clays. However, in the upper part, defined as subunit IIA, some ash layers are present. The lowest part of unit II, called subunit IIB, is entirely composed of pelagic clays. The transition between subunit IIB and unit III is marked by the presence of zeolitic clays. The ages within unit II remain unknown by lack of paleomagnetic or biostratigraphic data but the unit reflects most of the age history of the site (from 6.6 Ma to $105 \mathrm{Ma}$ [Plank et al., 2007]).

[12] 3. Unit III mainly consists of biogenic siliceous deposits: radiolarian cherts and radiolarian porcelanite. Some claystones were also recovered, essentially in the uppermost and in the lowest part of the unit. The thickness of unit III is about $103 \mathrm{~m}$ and its deposition age ranges from 105 to $127 \mathrm{Ma}$ [Plank et al., 2007].

[13] 4. Unit IV has a thickness of $126 \mathrm{~m}$ and is characterized by a mixture of radiolarian cherts and porcelanite with calcareous sediments (marlstone and chalk). An isolated ash-rich level is also present at the top of the unit. Nannofossils preserved in marls and chalks indicate a late Valanginian (134 Ma) to late Hauterivian (127 Ma) age for this unit.

[14] Discrete samples were selected along the entire Site 1149 sedimentary column from unit I to unit IV [Plank et al., 2000]. Their major and trace element compositions were measured by Plank et al. [2007] and we report here Hf and Nd isotopic compositions on a selection of this sediment set. Eighteen samples from the various lithologies were selected in the different units to cover the entire compositional spectrum. This same subset of samples have been studied by several investigators, and so together, form a remarkably complete data set for elemental and isotopic compositions [Ludden et al., 2006; Plank et al., 2007]. The measured Hf and $\mathrm{Nd}$ isotopic variations should therefore be representative of the entire sedimentary pile.

\section{Analytical Procedure}

[15] Hf and $\mathrm{Nd}$ chemical separation were performed in Grenoble and the isotopic compositions were measured using the VG Plasma 54 at ENS Lyon. Samples were dissolved in Savillex beakers but dissolution in Parr bombs were also performed on selected samples to check that complete dissolution of the sediments was achieved (see Table 2). The analytical procedure for Hf separation was based on the method published by Blichert-Toft et al. [1997] which proved to be highly efficient for most of the Site 801C composites and Site 1149 sediments, but this method failed for two particular sample groups (cherts and Ca-rich sediments) and had to be modified. Detailed suggestions relative to the isolation of Hf for these two groups of sediments are given in the appendix. Nd was isolated from the other REE using the classical Eichrom ${ }^{\mathrm{R}}$ HDEHP-coated Teflon resin technique. $\mathrm{Hf}$ and $\mathrm{Nd}$ blanks were measured regularly by ICP-MS and were always lower than $80 \mathrm{pg}$ for Hf and $235 \mathrm{pg}$ for $\mathrm{Nd}$; these values are negligible relative to the amounts of $\mathrm{Hf}$ and $\mathrm{Nd}$ present in the samples.

[16] Accuracy of the isotopic measurements was monitored on the P54 at ENS Lyon using the JMC$475 \mathrm{Hf}$ standard. The average measured ${ }^{176} \mathrm{Hf} /{ }^{177} \mathrm{Hf}$ ratio was $0.282163 \pm 11$ ( $1 \sigma, 32$ runs). Two different standards were used during $\mathrm{Nd}$ analysis: an internal "home" $\mathrm{Nd} \mathrm{JMC} \mathrm{standard} \mathrm{which} \mathrm{gave}$ an average ${ }^{143} \mathrm{Nd} /{ }^{144} \mathrm{Nd}$ ratio of $0.512238 \pm 7(1 \sigma$, 12 runs) and the $\mathrm{Nd}$ La Jolla standard which gave an average ${ }^{143} \mathrm{Nd} /{ }^{144} \mathrm{Nd}$ ratio of $0.511858 \pm 10(1 \sigma$, 8 runs). Several complete duplicate analyses were performed and results show that for both $\mathrm{Nd}$ and Hf isotopic ratios, the measurements reproduce within analytical errors $\left(\leq 1 \varepsilon_{\mathrm{Nd}}\right.$ or $\left.\varepsilon_{\mathrm{Hf}}\right)$ (see Tables 1 and 2).

\section{Results}

\subsection{Site 801C Basalt Composites}

[17] Hf and $\mathrm{Nd}$ isotopic compositions of Hole $801 \mathrm{C}$ composites are reported in Table 1 together with calculated present-day and initial $\varepsilon_{\mathrm{Hf}}$ and $\varepsilon_{\mathrm{Nd}}$ values. The lithology of each composite is also indicated in the footnote. The measured and initial $\mathrm{Hf}$ and $\mathrm{Nd}$ isotopic compositions of Hole 801C samples are plotted in Figure 3 together with values for present-day mid-ocean ridge basalts (MORB) and oceanic island basalts (OIB). Figure 3 shows that the MORB composites have $\mathrm{Hf}$ and $\mathrm{Nd}$ isotopes indistinguishable from those of present-day Pacific MORB. The three alkali basalt composites have very different isotopic compositions and plot in the OIB field close to some of the Austral HIMU samples. When compared to the four samples from 
Table 1. Hf and Nd Isotopic Compositions of Hole 801C Composites

\begin{tabular}{|c|c|c|c|c|c|c|c|}
\hline Composites $^{\mathrm{a}}$ & Type & ${ }^{143} \mathrm{Nd} /{ }^{144} \mathrm{Nd} \pm 2 \sigma_{\mathrm{m}}{ }^{\mathrm{b}}$ & $\varepsilon_{\mathrm{Nd}}^{\mathrm{c}}$ & $\varepsilon_{\mathrm{Nd}}(\mathrm{i})^{\mathrm{d}}$ & ${ }^{176} \mathrm{Hf} /{ }^{177} \mathrm{Hf} \pm 2 \sigma_{\mathrm{m}}{ }^{\mathrm{b}}$ & $\varepsilon_{\mathrm{Hf}}^{\mathrm{c}}$ & $\varepsilon_{\mathrm{Hf}}(\mathrm{i})^{\mathrm{d}}$ \\
\hline 801-TAB-0-50 & FLO & $0.512845 \pm 13$ & +4.0 & +5.4 & $0.282979 \pm 7$ & +7.3 & +9.9 \\
\hline 801-TAB-0-50 & VCL & $0.512848 \pm 9$ & +4.1 & +5.4 & $0.283019 \pm 6$ & +8.7 & +10.9 \\
\hline 801-TAB-0-50 & All & $0.512896 \pm 6$ & +5.0 & +6.3 & $0.282973 \pm 5$ & +7.1 & +9.6 \\
\hline 801-MORB-0-110 & FLO & $0.513154 \pm 32$ & +10.1 & +9.7 & $0.283206 \pm 6$ & +15.3 & +15.8 \\
\hline 801-MORB-0-110 & All & $0.513081 \pm 10$ & +8.6 & +8.3 & $0.283201 \pm 5$ & +15.2 & +15.3 \\
\hline 801-MORB-110-220 & FLO & $0.513128 \pm 9$ & +9.6 & +9.2 & $0.283171 \pm 6$ & +14.1 & +14.8 \\
\hline 801-MORB-110-220 & VCL & $0.513080 \pm 6$ & +8.6 & +8.4 & $0.283219 \pm 9$ & +15.8 & +15.4 \\
\hline 801-MORB-110-220 & All & $0.513103 \pm 7$ & +9.1 & +8.8 & $0.283194 \pm 8$ & +14.9 & +15.4 \\
\hline 801-MORB-220-420 & FLO & $0.513154 \pm 8$ & +10.1 & +9.8 & $0.283172 \pm 7$ & +14.1 & +14.7 \\
\hline 801-MORB-220-420 & VCL & $0.513157 \pm 5$ & +10.1 & +9.8 & $0.283201 \pm 5$ & +15.2 & +15.7 \\
\hline 801-MORB-220-420 & $\mathrm{VCL}^{\mathrm{e}}$ & $0.513159 \pm 4$ & +10.2 & +9.9 & & & \\
\hline 801-MORB-220-420 & All & $0.513132 \pm 7$ & +9.6 & +9.3 & $0.283161 \pm 6$ & +13.8 & +14.3 \\
\hline 801 & SUPER & $0.513118 \pm 6$ & +9.4 & +9.1 & $0.283164 \pm 7$ & +13.9 & +14.3 \\
\hline
\end{tabular}

${ }^{\mathrm{a}} \mathrm{TAB}$, top alkali basalts; MORB, mid-ocean ridge tholeiites; FLO, less altered flows and pillows; VCL, highly altered volcanoclastics; SUPER, all site 801 tholeiite.

${ }^{\mathrm{b}}$ Normalized for mass fractionation to ${ }^{146} \mathrm{Nd} /{ }^{144} \mathrm{Nd}=0.7219$ and ${ }^{179} \mathrm{Hf} /{ }^{177} \mathrm{Hf}=0.7325$.

${ }^{\mathrm{c}}$ The $\varepsilon_{\mathrm{Hf}}$ and $\varepsilon_{\mathrm{Nd}}$ have been calculated using ${ }^{176} \mathrm{Hf} /{ }^{177} \mathrm{Hf}_{\mathrm{CHUR}}=0.282772$ after Blichert-Toft and Albarède [1997] and ${ }^{143} \mathrm{Nd} /{ }^{144} \mathrm{Nd} \mathrm{CHUR}=$ 0.512638 .

${ }^{\mathrm{d}}$ The $\varepsilon_{\mathrm{Hf}}(\mathrm{i})$ and $\varepsilon_{\mathrm{Nd}}(\mathrm{i})$ have been calculated using the trace element data published by Kelley et al. [2003] and the following ages: alkali materials $157 \mathrm{Ma}$ and tholeiitic materials $167 \mathrm{Ma}$ [Pringle, 1992]; ${ }^{176} \mathrm{Lu} /{ }^{177} \mathrm{Hf}$ CHUR(0) $=0.0332$ after Blichert-Toft and Albarède [1997] and ${ }^{147} \mathrm{Sm} /{ }^{144} \mathrm{Nd}_{\mathrm{CHUR}(0)}=0.1967$.

${ }^{\mathrm{e}}$ Complete duplicate analysis

site 801 (2 MORB and 2 OIB) analyzed by Pearce et al. [1999], a slight discrepancy is observed (see Figure 3): while the initial $\varepsilon_{\mathrm{Hf}}$ are comparable, our analyses are systematically lower for $\mathrm{Nd}$. The origin of the discrepancy is unclear because our $\mathrm{Nd}$ La Jolla measurements are similar to the value mentioned by Pearce et al. [1999].

\subsection{Site 1149 Sediments}

[18] The measured $\mathrm{Hf}$ and $\mathrm{Nd}$ isotopic ratios for Site 1149 sediments are reported in Table 2. Initial $\varepsilon_{\mathrm{Hf}}$ and $\varepsilon_{\mathrm{Nd}}$ values were also calculated using paleomagnetic and biostratigraphic ages [Bartolini, 2003] for samples from units I, III, and IV. For units IIA and IIB, ages are unknown by lack of magnetostratigraphic or biostratigraphic record. However, the sedimentation rate was particularly slow during deposition of these units, at about $1 \mathrm{~m} / \mathrm{Ma}$ if calculated over the entire time period and it does not seem to have varied through time. The initial $\mathrm{Hf}$ and $\mathrm{Nd}$ isotopic compositions of samples from units IIA and IIB were therefore calculated using this sedimentation rate and the depth at which samples occur.

[19] The initial $\varepsilon_{\mathrm{Hf}}$ and $\varepsilon_{\mathrm{Nd}}$ of all samples are plotted along the sedimentary column in Figure 4 . The $\varepsilon_{\mathrm{Nd}(\mathrm{i})}$ values define a limited range between -8 and -5 with three exceptions, two samples from Unit I and one sample from Unit IV, which all have significantly more radiogenic $\mathrm{Nd}$ isotopic compositions ( -3 to -1.6$)$. Hauff et al. [2003] also reported $\mathrm{Nd}$ isotopic compositions obtained on samples from the same Leg and eight of our samples were also measured by them for $\mathrm{Nd}, \mathrm{Sr}$, and $\mathrm{Pb}$ isotopes. Reported values are in excellent agreement and the difference between our values and those reported by Hauff et al. [2003] is always smaller than 50 ppm.

[20] Hf isotopes do not define the same pattern as $\mathrm{Nd}$ isotopes: while sediments from the top of the column have positive $\varepsilon_{\mathrm{Hf}(\mathrm{i})}$ values at about +6 , samples from the bottom of the pile have negative $\varepsilon_{\mathrm{Hf(i)}}$ values at about -5 , and the change occurs gradually through time. Two samples from the bottom of the pile and one sample from the top of the pile do not follow the general trend and have significantly more positive $\varepsilon_{\mathrm{Hf(i)}}$ at $+10.3,+8$, and +12 (see Table 2 and Figure 4). When plotted in a $\varepsilon_{\mathrm{Hf}(\mathrm{i})} \operatorname{versus} \varepsilon_{\mathrm{Nd}(\mathrm{i})}$ diagram (Figure 5), the Site 1149 sediments can be compared to the various types of oceanic sediments that have been published in the literature. This figure shows that almost all Site 1149 sediments plot in the Fe-Mn crusts and nodule field, above the "terrestrial array" defined by Vervoort et al. [1999]. In addition, the progressive increase 
Table 2. Hf and Nd Isotopic Compositions of Site 1149 Sediments

\begin{tabular}{|c|c|c|c|c|c|c|c|c|c|c|}
\hline Sample & $\begin{array}{c}\text { Depth }^{\mathrm{a}} \\
(\mathrm{mbsf})\end{array}$ & Unit & Dissolution & Protocol $^{\mathrm{b}}$ & $\begin{array}{c}{ }^{143} \mathrm{Nd} /{ }^{144} \mathrm{Nd} \pm \\
2 \sigma_{\mathrm{m}}{ }^{\mathrm{c}}\end{array}$ & $\varepsilon_{\mathrm{Nd}}{ }^{\mathrm{d}}$ & $\varepsilon_{\mathrm{Nd}(\mathrm{i})}{ }^{\mathrm{e}}$ & $\begin{array}{c}{ }^{176} \mathrm{Hf} /{ }^{177} \mathrm{Hf} \pm \\
2 \sigma_{\mathrm{m}}^{\mathrm{c}}\end{array}$ & $\varepsilon_{\mathrm{Hf}}{ }^{\mathrm{d}}$ & $\varepsilon_{\mathrm{Hf}(\mathrm{i})}{ }^{\mathrm{e}}$ \\
\hline $9 \mathrm{~A} 1 \mathrm{H} 1$ & & I & & 97 & $0.512369 \pm 10$ & -5.2 & -5.2 & $0.282966 \pm 8$ & +6.9 & +6.9 \\
\hline 1149A $1 \mathrm{H} 1140-150^{\mathrm{f}}$ & 1.40 & I & in Parr Bomb & BT 97 & & & & $0.282964 \pm 5^{\mathrm{g}}$ & +6.8 & +6.8 \\
\hline 1149A 4H2 140-150 & 26.10 & I & & BT 97 & $0.512307 \pm 5$ & -6.5 & -6.4 & $0.282939 \pm 9$ & +5.9 & +5.9 \\
\hline 1149A $4 \mathrm{H} 2140-150^{\mathrm{f}}$ & 26.10 & $\mathrm{I}$ & & BT 97 & $0.512271 \pm 6$ & -7.2 & -7.2 & & & \\
\hline 1149A 7H4 140-150 & 57.60 & I & & & $0.512557 \pm 6$ & -1.6 & -1.6 & \pm 8 & +10.3 & +10.3 \\
\hline 1149A 10H3 140-150 & 84.60 & I & & BT 97 & $0.512483 \pm 4$ & -3.0 & -3.0 & $0.282973 \pm 4^{\mathrm{g}}$ & +7.1 & +7.1 \\
\hline $1149 \mathrm{~A} 10 \mathrm{H} 3140-150^{\mathrm{f}}$ & 84.60 & I & & BT 97 & $0.512507 \pm 5$ & -2.6 & -2.5 & & & \\
\hline A $14 \mathrm{H} 21$ & 121.10 & IIA & & BT 97 & 0.512 & -6.8 & -6.6 & 0.2829 & +6.6 & +6.7 \\
\hline A $18 \mathrm{H} 31$ & 160.40 & IIB & Bomb & BT 97 & & & & 0.282 & +1.6 & +1.6 \\
\hline A $18 \mathrm{H} 3140-1$ & 160.40 & IIB & in Parr Bomb & BT 97 & & & & 0.282 & +0.7 & +0.7 \\
\hline 1149A 20X1 140-150 & 171.20 & IIB-III & & BT 97 & 0.51 & -5.8 & -5.4 & 0.2829 & +5.8 & +3.7 \\
\hline 1149B 6R1 38-42 & 199.08 & III & in Par & Ca-Depl & 0.5 & -6.4 & -5.8 & $0.282873 \pm 8^{\mathrm{g}}$ & +3.6 & +2.2 \\
\hline 1149B 12RCC $0-5$ & 245.40 & III & in Parı & Ca-Depl & $0.512294 \pm 5$ & -6.7 & -5.8 & 0.282 & -0.4 & -1.4 \\
\hline 1149B 16R1 93-98 & 283.23 & IV & & BT 97 & $0.512519 \pm 6$ & -2.3 & -1.1 & 0.282 & +6.4 & +8.0 \\
\hline 1149B 17R1 14-17 & 292.14 & IV & & BT 97 & $0.512248 \pm 12$ & -7.6 & -6.3 & $0.282677 \pm 4$ & -3.4 & -2.7 \\
\hline 1149B 17R1 $14-17^{\mathrm{f}}$ & 292.14 & IV & & BT 97 & & & & $0.282678 \pm 3^{\mathrm{g}}$ & -3.3 & -2.7 \\
\hline 1149B 18R1 41-43 & 302. & IV & & & 0 & - & 9 & $0.282692 \pm 5$ & -2.8 & -3.1 \\
\hline 0 & & IV & & & & -7.2 & -5.8 & & & \\
\hline $22 \mathrm{R} 12$ & & IV & & BT 9 & 8 & -7.8 & -6.5 & 0.28 & -3.6 & -3.3 \\
\hline 3 25R1 19-23 & 368.89 & IV & in Parr Bomb & Ca-Rich & & & & $0.282715 \pm 9^{g}$ & -2.0 & -5.4 \\
\hline 1149B 27R1 49-55 & 388.09 & IV & & Ca-Rich & 0.51 & -6.9 & -5.5 & & & \\
\hline 1149B 28R1 52-56 & 397.62 & IV & & BT 97 & $0.512353 \pm 77$ & -5.6 & -4.1 & & & \\
\hline 1149B 28R2 48-66 & 398.90 & IV & & BT 97 & $0.512312 \pm 24$ & -6.4 & -4.9 & & & \\
\hline 1149B 29R1 28-35 & 407.08 & IV & & BT 97 & & & & $0.283244 \pm 49$ & +16.7 & +12.0 \\
\hline
\end{tabular}

\footnotetext{
${ }^{\mathrm{a}}$ Here mbsf is meters below surface seafloor.

${ }^{\mathrm{b}}$ Protocol used for Hf separation: BT 97, original protocol of Blichert-Toft et al. [1997]; Ca-Depl and Ca-Rich, protocols for Ca-depleted and Ca enriched samples described in Figure A1 in Appendix A.

${ }^{\mathrm{c}}$ Normalized for mass fractionation to ${ }^{146} \mathrm{Nd} /{ }^{144} \mathrm{Nd}=0.7219$ and ${ }^{179} \mathrm{Hf} /{ }^{177} \mathrm{Hf}=0.7325$.

${ }^{\mathrm{d}}$ The $\varepsilon_{\mathrm{Hf}}$ and $\varepsilon_{\mathrm{Nd}}$ have been calculated using ${ }^{176} \mathrm{Hf} /{ }^{177} \mathrm{Hf}_{\mathrm{CHUR}}=0.282772$ after Blichert-Toft and Albarède [1997] and ${ }^{143} \mathrm{Nd} /{ }^{144} \mathrm{Nd} \mathrm{CHUR}_{\mathrm{CHU}}=$ 0.512638 .

${ }^{\mathrm{e}} \mathrm{The} \varepsilon_{\mathrm{Nd}(\mathrm{i})}$ and $\varepsilon_{\mathrm{Hf(i)}}$ have been calculated using the $\mathrm{Sm} / \mathrm{Nd}$ and $\mathrm{Lu} / \mathrm{Hf}$ ratios calculated from the trace element data published by Plank et al. [2007] and for Unit I, III, and IV sediments paleomagnetic and biostratigraphic ages reported by Plank et al. [2000]. Approximate ages of samples from unit II were determined by linear extrapolation from ages of unit I and III samples using a constant sedimentation rate of $1 \mathrm{~m} / \mathrm{Ma}$, ${ }^{176} \mathrm{Lu} /{ }^{177} \mathrm{Hf}_{\mathrm{CHUR}(0)}=0.0332$ after Blichert-Toft and Albarède [1997] and ${ }^{147} \mathrm{Sm} /{ }^{144} \mathrm{Nd}$ CHUR(0) $=0.1967$. Assuming a $5 \%$ error on the measured parent/daughter ratios, the error propagation on the calculated $\varepsilon_{(\mathrm{i})}$ due to the trace element ratio is always smaller than 0.1 epsilon unit.

${ }^{\mathrm{f}}$ Complete duplicate analysis.

${ }^{\mathrm{g}}$ Data published by Chauvel et al. [2008].
}

through time of $\varepsilon_{\mathrm{Hf}(\mathrm{i})}$ at constant $\varepsilon_{\mathrm{Nd}(\mathrm{i})}$ appears clearly: samples from unit IV are located next to the terrestrial array while samples from unit I have the most radiogenic Hf isotopes. Four exceptions exist, samples $7 \mathrm{H} 4$ and $10 \mathrm{H} 3$ from unit I and samples 16R1 and 29R1 from unit IV which have distinctively higher $\varepsilon_{\mathrm{Hf(i)}}$ or $\varepsilon_{\mathrm{Nd}(\mathrm{i})}$ values and do not plot along the general subvertical trend (Figure 5).

\section{Discussion}

\subsection{Composition of the Subducted Pile}

\subsubsection{Basalt Composites}

[21] In Site 801C, two volcanic sequences are distinguished, a thick pile of tholeiites overlain by a thin upper layer of more alkaline lavas. Composites of the tholeiitic rocks were prepared according to their depth along the drill core and according to the rock types [Kelley et al., 2003]. Suffixes on the sample name in Table 1 indicate the depth range mixed in the composite while the type of material is indicated as being flows (FLO), volcaniclastics (VCL), or a mixture of the two (ALL). In addition, a composite representative of the entire tholeiitic section was prepared and called 801 SUPER. All composites have near constant Hf and $\mathrm{Nd}$ isotopic compositions (see Figure 3) with $\varepsilon_{\mathrm{Hf}}$ and $\varepsilon_{\mathrm{Nd}}$ values similar to those of present-day Pacific MORB [Chauvel and Blichert-Toft, 2001], suggesting that the oceanic crust created about $167 \mathrm{Ma}$ ago [Pringle, 1992] originated from a mantle source equivalent to the present one. In addition, the similarity between this old Pacific oceanic crust and the basalts accreting today at the ridge suggests that alteration processes occurring after basalt formation at the ridge and during the 


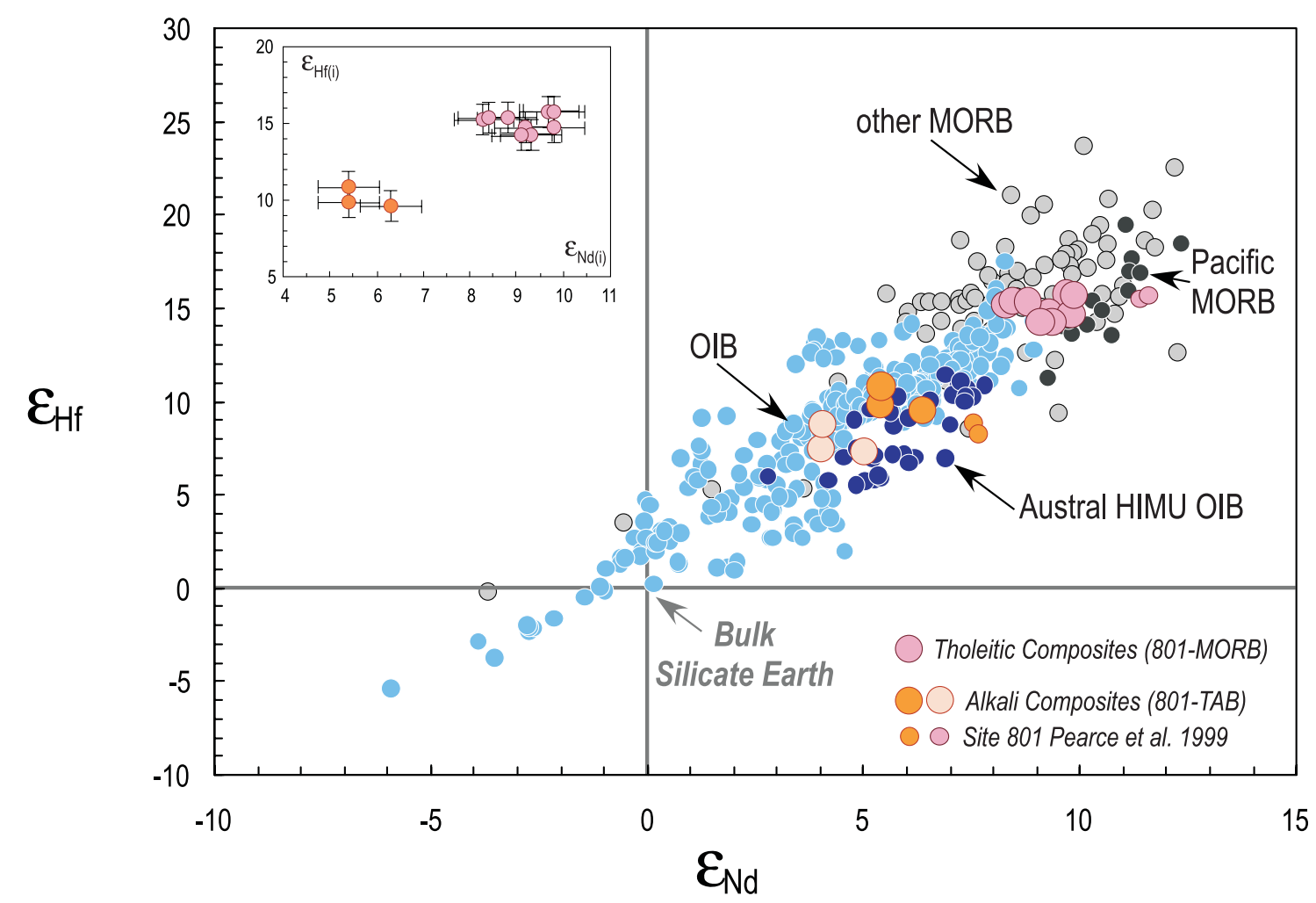

Figure 3. The $\varepsilon_{\mathrm{Hf}}$ versus $\varepsilon_{\mathrm{Nd}}$ diagram showing the measured and initial isotopic compositions of the composite basalts from Hole 801C relative to measurements published by Pearce et al. [1999] and the fields of present-day MORB and OIB. For the MORB composites, $\varepsilon_{\mathrm{Nd}}$ and $\varepsilon_{\mathrm{Hf}}$, and $\varepsilon_{\mathrm{Nd}(\mathrm{i})}$ and $\varepsilon_{\mathrm{Hf}(\mathrm{i})}$ are almost identical and are shown by only one symbol. In contrast, a difference of one to two $\varepsilon$ values is observed for the alkali basalts and the measured values are shown by the light color symbols while the initial values are shown by the orange dots. The HIMU islands in the Austral chain (Tubuai, Rurutu, and Raevavae) are shown with darker symbols. The inset in the upper left corner presents the initial $\varepsilon_{\mathrm{Hf}}$ and $\varepsilon_{\mathrm{Nd}}$ with uncertainties of about \pm 0.65 unit for the $\varepsilon_{\mathrm{Nd}(\mathrm{i})}$ values and about \pm 1 unit for the $\varepsilon_{\mathrm{Hf(i)}}$ values. MORB and OIB data are compiled from Georoc (http://georoc.mpch-mainz.gwdg.de/georoc/) and PetDB (http://www.petdb.org) databases as well as unpublished data from C. Chauvel (2008).

$167 \mathrm{Ma}$ of presence at the bottom of the Pacific ocean did not affect the $\mathrm{Nd}$ and $\mathrm{Hf}$ isotopes. In detail, small isotopic variations exist but no systematic trend can be found. In particular, no change occurs between composites from the upper, middle, and lower part of the hole; in contrast, small but maybe systematic differences may exist between flow composites and volcaniclastic composites in terms of $\mathrm{Hf}$ isotopes alone with slightly more radiogenic values in the volcaniclastics than in the flows. However, the difference is so small that it might be an artifact due to the limited number of analyzed samples (see Table 1).

[22] The top alkali basalt composites (TAB in Table 1) have $\varepsilon_{\mathrm{Hf}(\mathrm{i})}$ and $\varepsilon_{\mathrm{Nd}(\mathrm{i})}$ values lower than the tholeiitic composites and plot in the OIB field in Figure 3 close to data reported for two Jurassic OIB samples drilled at Site 801 and analyzed by
Pearce et al. [1999] and close to Rurutu and Raevavae, two islands in the Austral chain in Polynesia [Chauvel et al., 1992, 1997; Lassiter et al., 2003; Pfänder et al., 2007] confirming the OIB characteristics suggested by previous studies [Castillo et al., 1992; Floyd and Castillo, 1992; Hauff et al., 2003]. In addition, the strong similarity between the Hf-Nd isotopic compositions of the alkali basalt composites and those of Rurutu and Raevavae supports Koppers et al. [2003b] reconstruction of the past history of the Austral HIMU hot spot in the Western Pacific.

[23] The unmodified initial $\mathrm{Hf}$ and $\mathrm{Nd}$ isotopic compositions of Site 801C tholeiitic composites together with the preserved isotopes of the alkali composites demonstrate that, when considered on the bulk scale of the crust, the overall $\mathrm{Hf}$ and $\mathrm{Nd}$ isotopic budget of altered basalts remains un- 

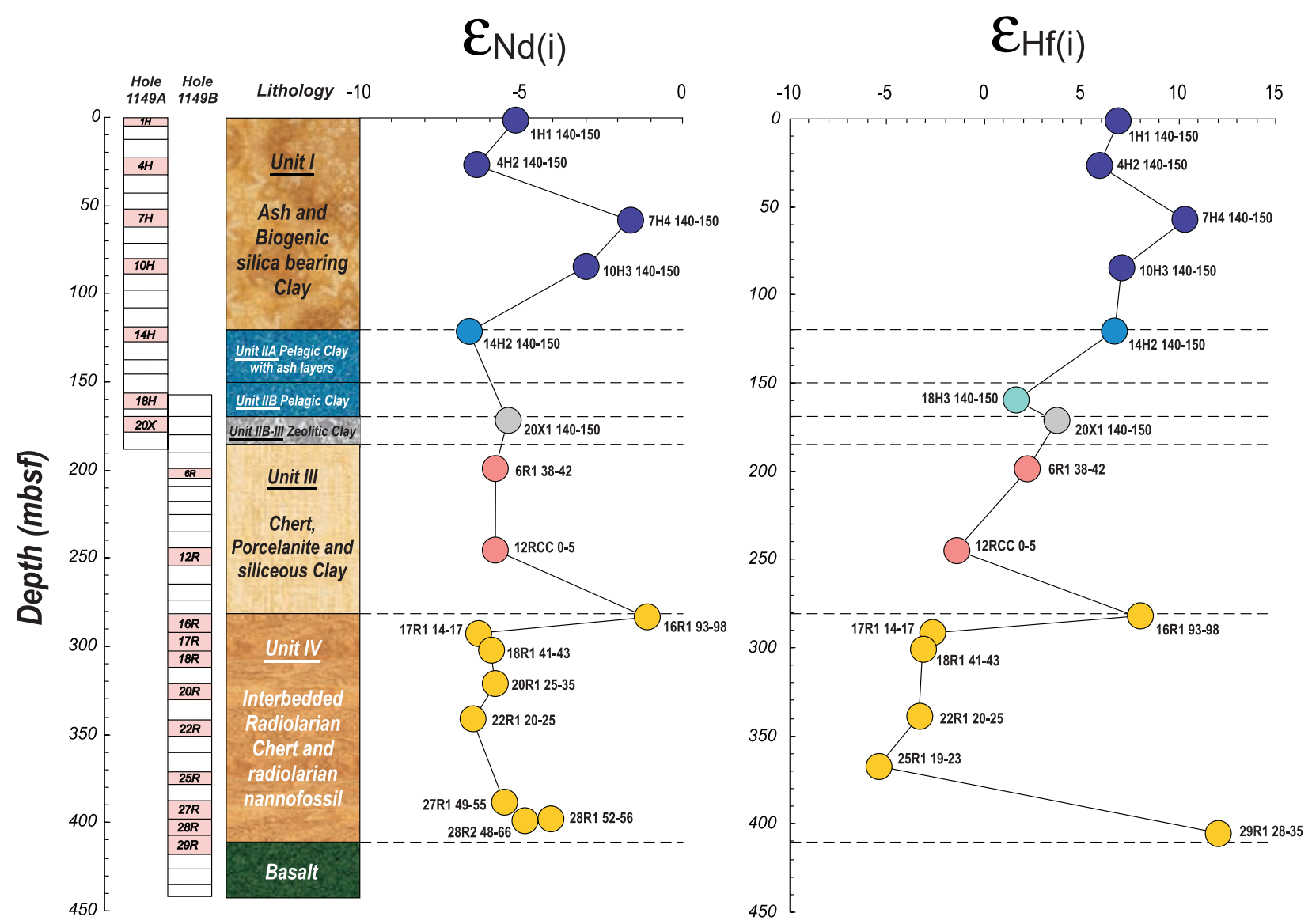

Figure 4. The $\varepsilon_{\mathrm{Nd}(\mathrm{i})}$ and $\varepsilon_{\mathrm{Hf}(\mathrm{i})}$ values of Site 1149 sediments plotted versus depth in the sedimentary pile.

changed during hydrothermal and low-temperature alteration processes. This result extends to the $\mathrm{Hf}$ isotopic system the conclusions reached in previous studies by Staudigel et al. [1995] who demonstrated that provided samples are large enough to represent the whole rock $(1-10 \mathrm{~cm}), \mathrm{Nd}$ isotopes of ocean basalts were not modified by hydrothermal alteration.

\subsubsection{Sedimentary Column}

[24] With the exception of four samples discussed later, the sediments sampled at Site 1149 have initial $\mathrm{Nd}$ isotopic compositions that, irrespective of their lithology and age, remain remarkably constant during the entire sedimentation history $\left(\varepsilon_{\mathrm{Nd}(\mathrm{i})}\right.$ vary only between -6.6 and -4 , see Table 2 and Figure 4). In contrast, their initial $\varepsilon_{\mathrm{Hf}}$ values increase systematically through time: the oldest sediments from Unit IV have the lowest $\varepsilon_{\mathrm{Hf}(\mathrm{i})}$ values at -5 while the most recent sediments from Unit I have positive $\varepsilon_{\mathrm{Hf}(\mathrm{i})}$ values above +5 (Figure 4). When combined in Figure 5, data points for the entire sediment pile fall in the field defined by the Fe-Mn crusts and nodules [Godfrey et al., 1997; Albarède et al., 1998; David et al., 2001], and systematically above the terrestrial array of Vervoort et al. [1999]. This suggests that during the $160 \mathrm{Ma}$ of oceanic sedimentation, the Hf-Nd budget of the sediments was mainly dominated by sources with radiogenic Hf isotopes relative to their $\mathrm{Nd}$ isotopic compositions, as is the case with the $\mathrm{Fe}-\mathrm{Mn}$ crusts and nodules, and was little influenced by direct detrital input from the continents. The reason why the older sediments register a more crustal signature than the younger sediments is unclear. Units III and IV are particularly poor in $\mathrm{Hf}$ and other trace elements due to the overwhelming presence of cherts and biogenic carbonates [Plank et al., 2007], while Units I and II contain a significant proportion of clays. The low $\varepsilon_{\mathrm{Hf}}$ values of the older sediments are therefore not associated to a high proportion of silicates coming from a continental source. In addition, $130 \mathrm{Ma}$ ago, the sediments were deposited far away from any 


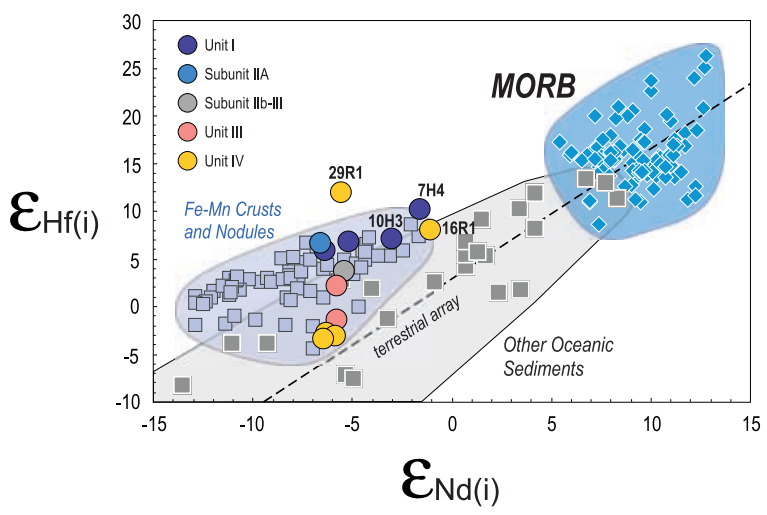

Figure 5. The $\varepsilon_{\mathrm{Hf}(\mathrm{i})}$ versus $\varepsilon_{\mathrm{Nd}(\mathrm{i})}$ diagram comparing the initial ratios calculated for Site 1149 sediments with those of Fe-Mn crusts and nodules and other oceanic sediments. Samples 7H4 140-150, 10H3 140-150, 16R1 93-98, and 29R1 28-35, with distinct features are marked. The $\mathrm{Nd}$ isotopic composition of sample 29R1 is from Hauff et al. [2003]. Fe-Mn crusts and nodules and other sediments data are from White et al. [1986], BenOthman et al. [1989], McLennan et al. [1990], Godfrey et al. [1997], Albarède et al. [1998], Pearce et al. [1999], Vervoort et al. [1999], and David et al. [2001]. "Terrestrial array" as defined by Vervoort et al. [1999] is also shown. MORB data sources as in Figure 3.

continent, in the middle of the gigantic Pacific superocean [Bartolini and Larson, 2001].

[25] There are four exceptions to this general trend: samples 29R1 and 16R1 from unit IV and samples $7 \mathrm{H} 4$ and $10 \mathrm{H} 3$ from unit I. Sample $29 \mathrm{R} 1$ is a calcareous marl located few centimeters above the basaltic basement. Plank et al. [2000, 2007] noticed that the lowermost sediments contain significant enrichments in metalliferous elements such as $\mathrm{Mn}$ and $\mathrm{Fe}$ and these sediments were interpreted as resulting from the presence of hydrothermal vents. While the $\mathrm{Nd}$ isotopic composition reported by Hauff et al. [2003] for sample 29R1 is similar to that of other samples, its $\mathrm{Sr}$ and $\mathrm{Pb}$ isotopic ratios are lower than in other samples. Our measured Hf isotopic composition for sample 29R1 is extremely radiogenic and approaches values obtained on the Site 801 basaltic basement. We suggest therefore that the Hf isotopic value reported for this sample is strongly influenced by the underlying basaltic crust, most likely due to hydrothermal sedimentation.

[26] Sample 16R1 from Unit IV and samples 7H4 and $10 \mathrm{H} 3$ from Unit I contain volcanic ashes in proportions varying between 10 and $15 \%$ [Plank et al., 2007], and their position in Figure 5 to the right of the trend defined by the other samples in the sedimentary pile can easily be explained by the contribution of volcanic products to the sediment composition. Plank et al. [2000] suggested that the volcanic ash present in samples $7 \mathrm{H} 4$ and $10 \mathrm{H} 3$ from Unit I could very well come from the Western Pacific volcanic arcs such as the Izu-BoninMarianne arc. This suggestion is entirely consistent with (1) the $\mathrm{Hf}$ and $\mathrm{Nd}$ isotopic compositions of the two samples from Unit I, which are displaced from the sediment pile field in Figure 5 toward more radiogenic isotopic compositions, and (2) the relationship between $\mathrm{Sm} / \mathrm{Nd}$ and $\varepsilon_{\mathrm{Nd}(\mathrm{i})}$ values shown in Figure 6 where samples $7 \mathrm{H} 4$ and $10 \mathrm{H} 3$ fall in between the field defined by the other sediments and the field defined by the Izu-Mariana volcanics. For sample 16R1 from Unit IV, the origin of the volcanic material is more difficult to evaluate because at the time when the sediment was deposited on the ocean floor, about $125 \mathrm{Ma}$ ago, it was located far from any known volcanic arc, volcanic island or continental arc (see Coffin et al. [2000] and Bartolini and Larson [2001] for paleogeographic reconstruction of the Pacific plate). However, its position in Figure 6 together with the widespread recognition of OIB-type volcanic products in this part of the Pacific at that time [Staudigel et al., 1991; Castillo et al., 1992; Floyd et al., 1992; Lees et al., 1992; Koppers et al., 2003b] suggests that the volcanic ashes probably came from an ocean island located within a few hundreds of kilometers.

[27] Our Hf and Nd isotopic measurements can be combined with trace element analyses published by Plank et al. [2007] to quantify the average composition of the entire sedimentary pile. Using an approach similar to that of Plank and Langmuir [1998] we use discrete measurements performed on carefully selected samples representative of each lithological unit to calculate the average composition of each lithology. A global average of the entire sedimentary pile was then calculated using the composition of each unit composition and their relative proportion in the sediment column. Results are shown in Table 3 and presented in Figure 7. The sedimentary pile drilled at Site 1149 was initially divided in five lithological units or subunits [see Plank et al., 2000, Figure F17]. However, trace element analysis [Plank et al., 2007] and $\mathrm{Hf}$ and $\mathrm{Nd}$ isotopes indicate the presence of some distinctive layers within the original units:

[28] 1. The transition between subunit IIB and unit III consists of $10 \mathrm{~m}$ of zeolitic clays highly enriched in REE compared to the rest of unit III and subunit IIB samples [Plank et al., 2007]. We 


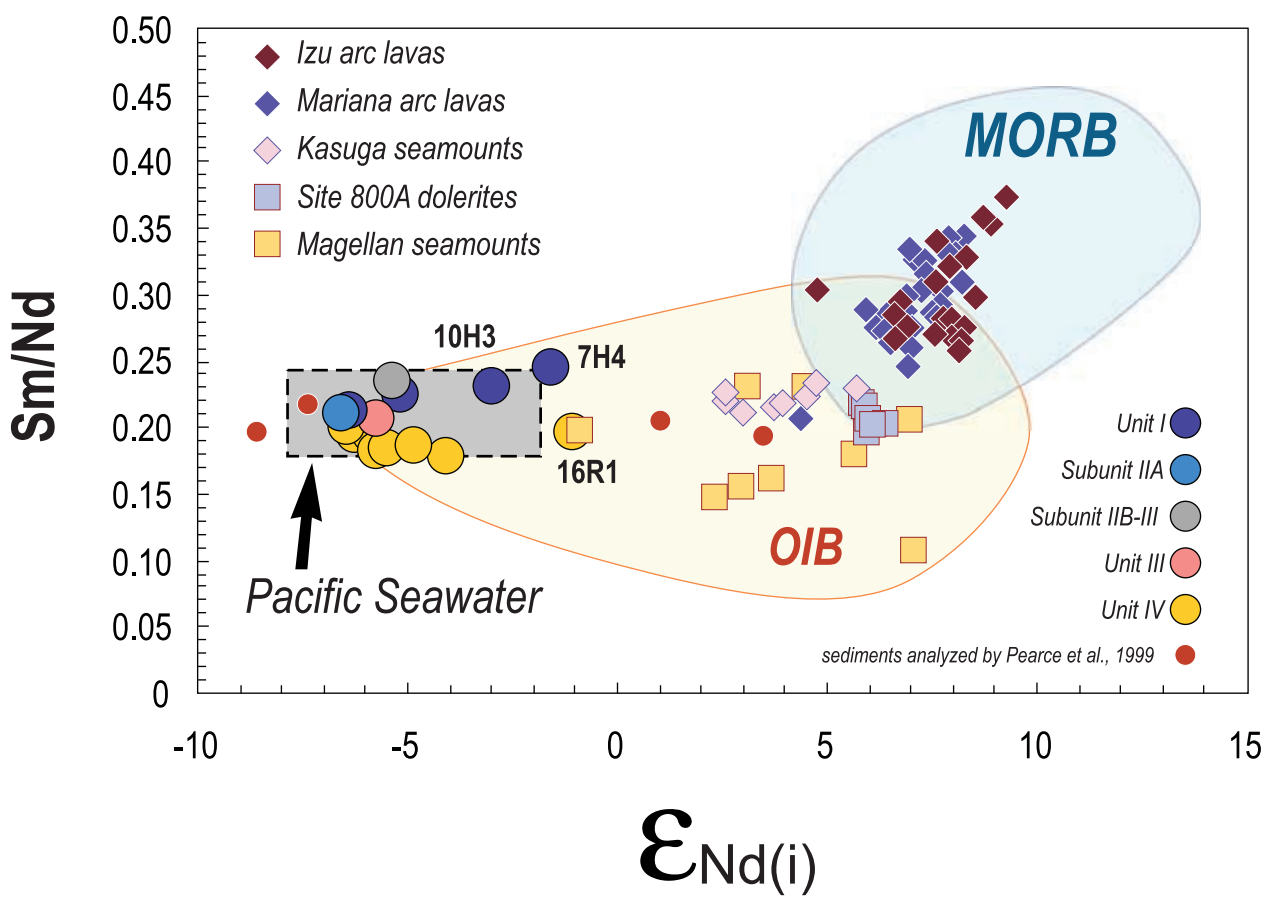

Figure 6. $\mathrm{Sm} / \mathrm{Nd}$ versus $\varepsilon_{\mathrm{Nd}(\mathrm{i})}$ diagram showing Site 1149 sediments together with the Pacific Seawater field, the Izu-Mariana arc lavas, the Site 800A alkali dolerites and OIB from Magellan seamounts. Trace element data of Site 1149 sediments are from Plank et al. [2007]. The Pacific Seawater field has been drawn using data published by Piepgras and Jacobsen [1988] and Shimizu et al. [1994]. Izu-Mariana arc lavas are from White and Patchett [1984], Woodhead [1989], Elliott et al. [1997], Pearce et al. [1999], Woodhead et al. [2001], Wade et al. [2005], Tollstrup and Gill [2005], and Stern et al. [2006]. Four sediments analyzed by Pearce et al. [1999] are shown with small brown dots. Site 800A dolerites data are from Floyd et al. [1992] and Castillo et al. [1992]. Magellan seamounts data are from Staudigel et al. [1991].

Table 3. Hf and Nd Bulk Isotopic Compositions and Trace Element Ratios for the Site 1149 Sedimentary Pile

\begin{tabular}{|c|c|c|c|c|c|c|c|c|c|c|c|c|}
\hline Unit & Mass $\%$ & ${ }^{143} \mathrm{Nd} /{ }^{144} \mathrm{Nd}^{\mathrm{a}}$ & $\varepsilon_{\mathrm{Nd}}{ }^{\mathrm{b}}$ & ${ }^{176} \mathrm{Hf} /{ }^{177} \mathrm{Hf}^{\mathrm{a}}$ & $\varepsilon_{\mathrm{Hf}}^{\mathrm{b}}$ & $\underset{(\mathrm{ppm})^{\mathrm{c}}}{\mathrm{Nd}}$ & $\underset{(\mathrm{ppm})^{\mathrm{c}}}{\mathrm{Sm}}$ & $\underset{(\mathrm{ppm})^{\mathrm{c}}}{\mathrm{Lu}}$ & $\begin{array}{c}\mathrm{Hf} \\
(\mathrm{ppm})^{\mathrm{c}}\end{array}$ & $\mathrm{Sm} / \mathrm{Nd}$ & $\mathrm{Nd} / \mathrm{Hf}$ & $\mathrm{Lu} / \mathrm{Hf}$ \\
\hline Site 1149 & 100 & 0.512336 & -5.9 & 0.282897 & +4.4 & 25.2 & 5.32 & 0.39 & 1.44 & 0.211 & 17.5 & 0.271 \\
\hline Unit I & 30.2 & 0.512423 & -4.2 & 0.282987 & +7.6 & 21.5 & 4.72 & 0.414 & 2.62 & 0.220 & 8.2 & 0.158 \\
\hline Subunit IIA & 6.5 & 0.512291 & -6.8 & 0.282960 & +6.6 & 26.5 & 5.90 & 0.521 & 3.05 & 0.223 & 8.7 & 0.171 \\
\hline Subunit IIB & 4.3 & & & 0.282816 & +1.6 & 59.4 & 13.3 & 0.994 & 4.14 & 0.224 & 14.3 & 0.240 \\
\hline Subunit IIB-III & 2.2 & 0.512342 & -5.8 & 0.282936 & +5.8 & 193.5 & 44.0 & 3.19 & 4.47 & 0.227 & 43.3 & 0.714 \\
\hline Unit III & 24.4 & 0.512296 & -6.7 & 0.282779 & +0.2 & 30.5 & 6.34 & 0.531 & 1.38 & 0.208 & 22.1 & 0.385 \\
\hline Sample 16R1 93-98 & 0.04 & 0.512519 & -2.3 & 0.282954 & +6.4 & 37.9 & 7.44 & 0.541 & 5.24 & 0.196 & 7.2 & 0.103 \\
\hline Unit IV & 32.2 & 0.512277 & -7.0 & 0.28 & -3.3 & 11.5 & 2.17 & 0.142 & 0.48 & 0.189 & 24.0 & 0.296 \\
\hline Sample 29R1 28-35 & 0.2 & & & 0.283244 & +16.7 & 20.1 & 3.74 & 0.332 & 0.55 & 0.186 & 36.5 & 0.604 \\
\hline
\end{tabular}

\footnotetext{
${ }^{\mathrm{a}}$ The isotopic composition of each unit has been calculated using the isotopic compositions and the $\mathrm{Nd}$ and Hf concentrations of discrete samples analyzed in each unit. The $\mathrm{Nd}$ and $\mathrm{Hf}$ isotopic compositions of the entire Site 1149 sedimentary pile have been calculated combining the isotopes, trace element compositions and mass \% of each unit and the mixing equation of Langmuir et al. [1978]. The trace element contents listed for the Site 1149 are from Plank et al. [2007].

${ }^{\mathrm{b}}$ The $\varepsilon_{\mathrm{Hf}}$ and $\varepsilon_{\mathrm{Nd}}$ have been calculated using ${ }^{176} \mathrm{Hf} /{ }^{177} \mathrm{Hf}_{\mathrm{CHUR}}=0.282772$ after Blichert-Toft and Albarède [1997] and ${ }^{143} \mathrm{Nd} /{ }^{144} \mathrm{Nd} \mathrm{CHUR}=$ 0.512638 .

${ }^{\mathrm{c}}$ Trace element data used for calculations. They differ slightly from values suggested by Plank et al. [2007] for individual units because we fell more comfortable calculating the average $\mathrm{Nd}$ and $\mathrm{Hf}$ isotopic compositions using samples that had been analyzed for isotopes instead of using the whole range of concentrations that vary quite widely in some of the units. The concentrations given on the first line for the entire Site 1149 are from Plank et al. [2007].
} 


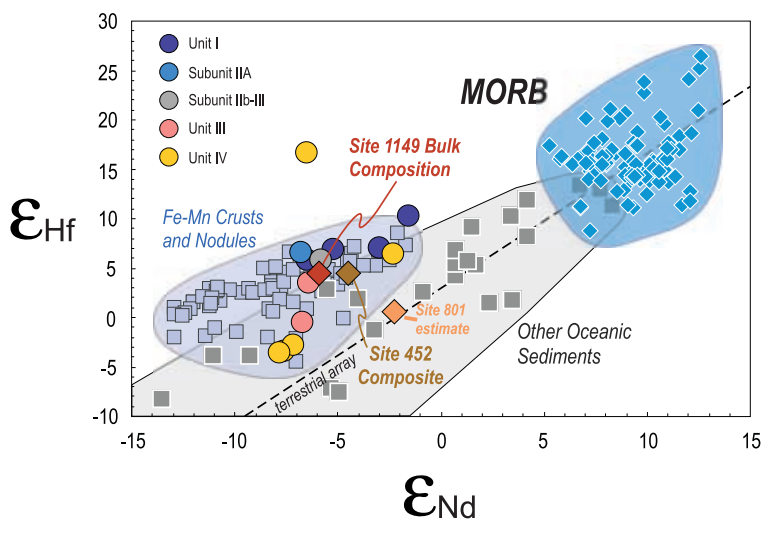

Figure 7. Present-day $\varepsilon_{\mathrm{Hf}}$ versus $\varepsilon_{\mathrm{Nd}}$ diagram of Site 1149 sediments together with Fe-Mn crusts and nodules and other oceanic sediments. Hf and $\mathrm{Nd}$ isotopes of a composite from DSDP Site 452 sedimentary pile are from Woodhead [1989] while values for Site 801 are from Wade et al. [2005]. Other data sources as in Figure 5. The positions of Site 1149 sediments in the figure differ slightly from their position in Figure 5 because here we plot present-day measured ratios while initial ratios were reported in Figure 5.

therefore treated this REE-rich layer individually when performing the average calculation.

[29] 2. Samples 16R1 93-98 and 29R1 28-35 from unit IV have radiogenic Hf isotopic compositions compared to the other unit IV sediments (Table 2) and were considered separately for the average calculation.

[30] The Site 1149 sedimentary column has an average $\varepsilon_{\mathrm{Nd}}$ that is negative at -5.9 , but its $\varepsilon_{\mathrm{Hf}}$ value is positive at about +4.4 . In Figure 7 , the combined values plot in the Fe-Mn crusts and nodules field significantly above the "terrestrial array" of Vervoort et al. [1999], suggesting that the REE and Hf budget for the entire history of sedimentation in the Pacific was dominated by mineral phases that registered a source with elevated Hf isotopes as is the case with the Fe-Mn crusts and nodules.

[31] Remarkably similar $\varepsilon_{\mathrm{Hf}}$ and $\varepsilon_{\mathrm{Nd}}$ values were obtained by White et al. [1986] and Woodhead [1989] who measured a composite sample from DSDP Site 452 located in front of the Mariana arc (see Figures 1 and 7). It is also not very different from the estimated average Site 801 sediment value calculated by Wade et al. [2005]. This suggests that the average isotopic compositions obtained in this study represent a common feature for the Western Pacific sedimentary cover. However, both at DSDP
Site 452 in front of the Mariana arc and at ODP Site 1149 in front of the Izu arc, the sedimentary columns do not include much volcanoclastic sediments [Hussong et al., 1982; Plank et al., 2000] whose presence would affect the average composition of the sediment cover. In other locations such as the West Pacific ODP sites 800, 801, and 802 (see Figure 1) thick volcanoclastic units are present [Lancelot et al., 1990; Lees et al., 1992] and there, the average $\mathrm{Hf}$ and $\mathrm{Nd}$ isotopic compositions would probably be different, with more radiogenic $\mathrm{Nd}$ and $\mathrm{Hf}$ isotopic values. The average $\mathrm{Hf}$ and $\mathrm{Nd}$ isotopic compositions of DSDP Site 452 and ODP Site 1149 should therefore be considered as representative of Pacific sedimentary columns dominated by pelagic sediments.

\subsection{Recycling of the Site 1149 Sediments in the Izu-Mariana Arc System}

[32] The trace element and isotopic characteristics of Izu arc lavas are reported in several papers [Notsu et al., 1983; Ikeda and Yuasa, 1989; Fryer et al., 1990; Hochstaedter et al., 1990a, 1990b; Tatsumi et al., 1992; Taylor and Nesbitt, 1998; Ishikawa and Tera, 1999; Hochstaedter et al., 2000, 2001; Schmidt, 2001; Straub and Layne, 2002; Straub, 2003; Straub et al., 2004] but the number of samples analyzed for Hf isotopes is quite limited. In terms of $\mathrm{Hf}$ and $\mathrm{Nd}$ isotopic compositions, Izu lavas, together with the Mariana arc lavas, are among the most radiogenic arc lavas studied up to now [White and Patchett, 1984; Woodhead, 1989; Pearce et al., 1999; Woodhead et al., 2001; Tollstrup and Gill, 2005; Wade et al., 2005; Stern et al., 2006]: their Hf and Nd isotopic characteristics are not very different from those of MORB (see Figure 8). Using our estimate of the average composition of the subducted sediments, we can evaluate the proportion of sediments involved in the genesis of the arc lavas. The composition of the mantle contaminated by the sediments is a matter of debate; it could either be Indian type MORB mantle as suggested by HickeyVargas [1998], Savov et al. [2006], Pearce et al. [1999], and by Woodhead et al. [2001], or Pacifictype MORB mantle. Here we calculated mixing arrays using a Pacific mantle because this evaluation provides a higher proportion of sedimentary material due to the more radiogenic $\mathrm{Nd}$ isotopic composition of the Pacific mantle; it is therefore the maximum possible contribution from the sedimentary pile. In addition, some of the data used to suggest that the mantle wedge has "Indian" char- 


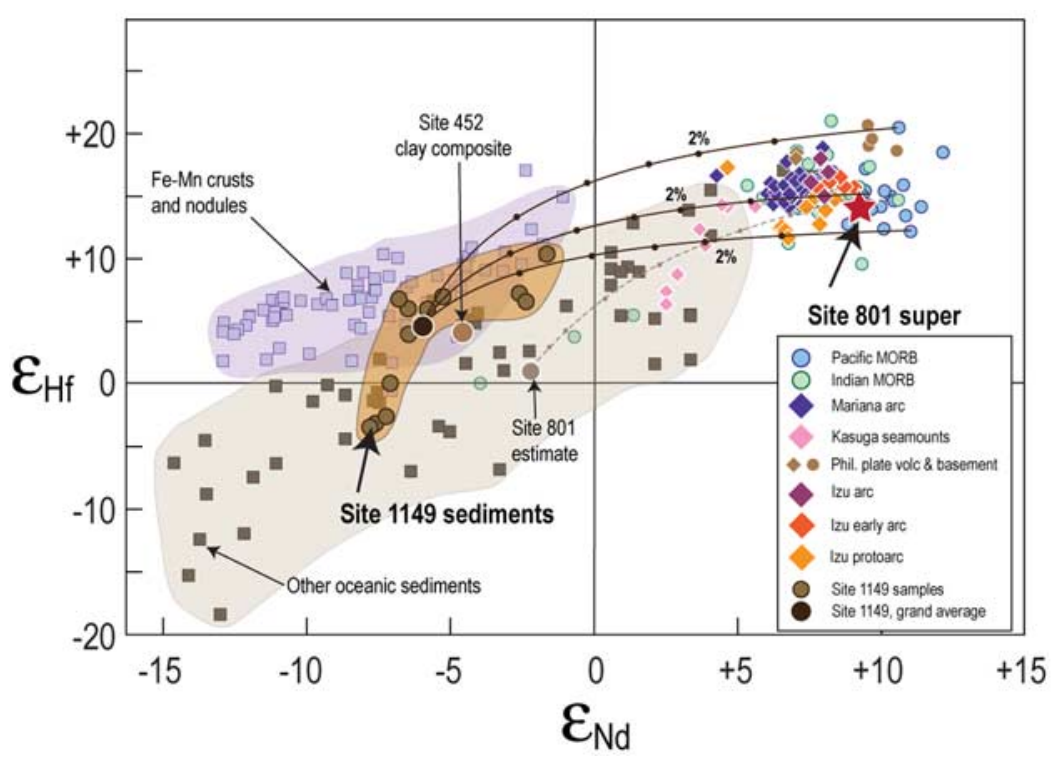

Figure 8. ${ }^{176} \mathrm{Hf} /{ }^{177} \mathrm{Hf}$ versus ${ }^{143} \mathrm{Nd} /{ }^{144} \mathrm{Nd}$ for sediments, Izu-Bonin-Mariana arc lavas and Pacific and Indian MORB showing that less than $2 \%$ sediment combined with Pacific MORB mantle is enough to explain the composition of the arc lavas. The sediment composition of Site 1149 is given in Table 4 and the depleted mantle compositions are evaluated as follows: (1) Nd and Hf concentrations are from Salters and Stracke [2004]; (2) three different isotopic compositions were selected: our estimated average composition for Pacific MORB: $\varepsilon_{\mathrm{Nd}}=+9.7$ and $\varepsilon_{\mathrm{Hf}}=+15$, the sample with the most radiogenic Hf isotopes: $\varepsilon_{\mathrm{Nd}}=+10.8$ and $\varepsilon_{\mathrm{Hf}}=+20.1$, and the sample with the least radiogenic Hf isotopes: $\varepsilon_{\mathrm{Nd}}=+11.2$ and $\varepsilon_{\mathrm{Hf}}=+12.1$. Three mixing arrays are shown between sediment and the three depleted mantle sources. The mixing arrays were calculated assuming bulk mixtures of sediment and mantle. The sediment proportions are therefore maximum proportions because if the sediment component is extracted through either a melt or a fluid phase, the trace element concentrations of the contaminant should be higher than the starting sediment concentrations. The mixing array between Site 801 estimate [Wade et al., 2005] and average Pacific mantle, shown with a dashed brown curve, passes well below the arc lava fields. If an Indian-type mantle is used instead of a Pacific depleted mantle, the proportion of sediment required to explain the Izu-Mariana arc data is even lower, at less than 1\%. Data sources as in Figures 4, 5, and 6 plus sediment data from Vlastelic et al. [2005] and Philippine plate basement and volcanic clasts from Pearce et al. [1999] and Savov et al. [2006].

acteristics are ambiguous. The samples from the Philippine basement analyzed by Savov et al. [2006] and by Pearce et al. [1999] plot in between the Indian and the Pacific MORB fields in Nd-Hf isotopic space (see Figure 8). Moreover, the overlap between the Philippine plate and the Indian MORB as shown by Hickey-Vargas [1998] and by Savov et al. [2006] is accentuated by using initial ratios of the $45 \mathrm{Ma}$ volcanics versus present-day isotopic ratios for MORB. The age correction has a significant impact on the ${ }^{206} \mathrm{~Pb} /{ }^{204} \mathrm{~Pb}$ and ${ }^{143} \mathrm{Nd} /{ }^{144} \mathrm{Nd}$ ratios but not on the ${ }^{207} \mathrm{~Pb} /{ }^{204} \mathrm{~Pb}$, ${ }^{208} \mathrm{~Pb} /{ }^{204} \mathrm{~Pb}$, and ${ }^{176} \mathrm{Hf} /{ }^{177} \mathrm{Hf}$ ratios. When the measured ratios are compared to the present-day MORB fields, data plot at an ambiguous intermediate position. Thus, while mantle of Indian affinity may have generated some Philippine basement, its distribution beneath the modern arcs is unknown, and given the subtle shifts in $\mathrm{Nd}$ and $\mathrm{Hf}$ that have been observed even in these "Indian" provinces, we chose the more extreme Pacific end-member to provide maximum sediment contributions.

[33] Mixing arrays between the average subducted sediments and Pacific mantle are calculated using end-member compositions given in the caption of Figure 8 and shown in Figure 8. They fit well the data reported for both Izu and Mariana arc lavas and suggest that less than $2 \%$ of sediment mixed with depleted mantle can reproduce the island arc Hf-Nd isotopic array. This percentage is very similar to the proportion of sediment suggested by Wade et al. [2005] for the Mariana arc and it is consistent with estimates based on other trace elements or isotopic systems [i.e., Tera et al., 1986; Ryan and Langmuir, 1988; Woodhead et al., 2001]. If Indian type mantle were used instead of Pacific mantle composition, the proportion of sediment would be lower. The position of Site 1149 average sediment composition in the Hf-Nd 

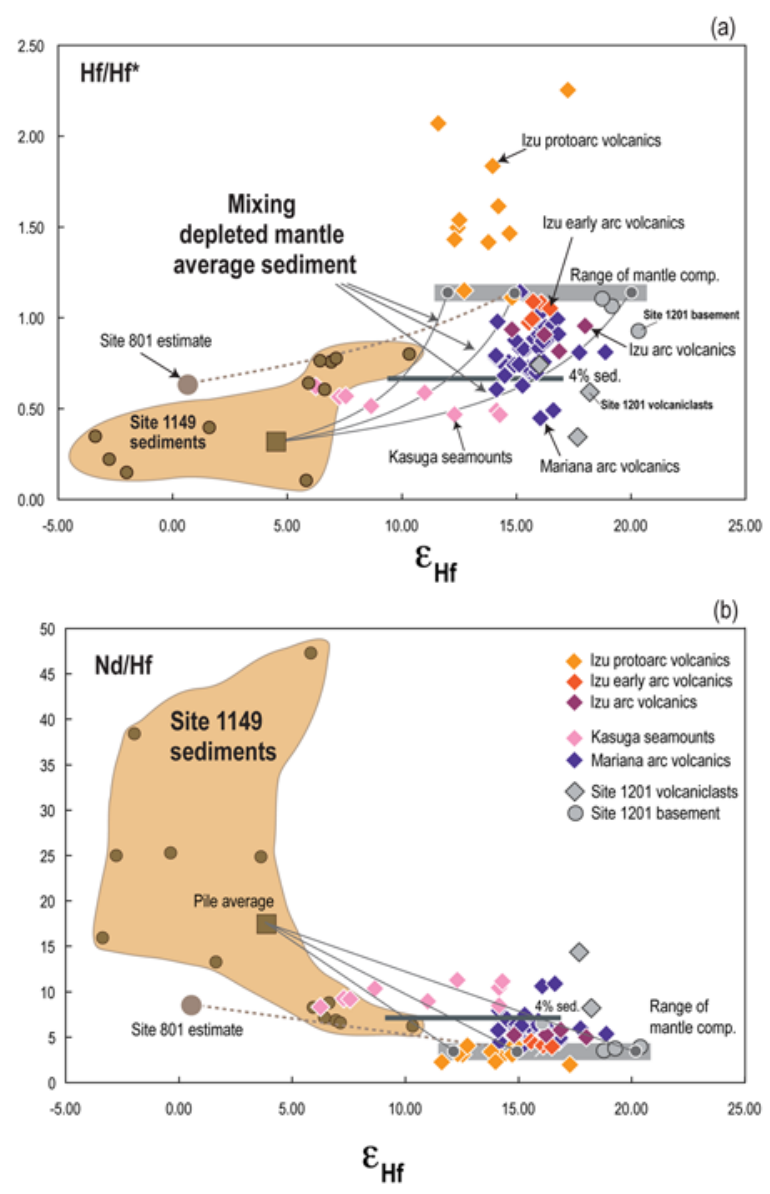

Figure 9. (a) $\mathrm{Hf} / \mathrm{Hf}^{*}$ versus $\varepsilon_{\mathrm{Hf}}$ and (b) $\mathrm{Nd} / \mathrm{Hf}$ versus $\varepsilon_{\mathrm{Hf}}$ showing mixing arrays between the average Site 1149 sediment and the same three potential depleted mantle sources as in Figure 8. With the exception of the Kasuga seamounts and the Izu protoarc volcanics, most Izu and Mariana arc volcanics can be explained by less than $4 \%$ sediment in the contaminated mantle source. Calculations were performed as in Figure 8 and the data sources are as in Figures 5, 6, 7, and 8. Hf/Hf* measures the size of the primitive mantle normalized Hf anomaly calculated using the following equation: $\mathrm{Hf} / \mathrm{Hf}^{*}=\mathrm{Hf}_{\mathrm{N}} /$ $\left(\left(\mathrm{Nd}_{\mathrm{N}}+\mathrm{Sm}_{\mathrm{N}}\right) / 2\right)$ and the normalizing values of Hofmann [1988]. As in Figure 8, the mixing array between Site 801 estimate [Wade et al., 2005] and depleted mantle does not intersect the island arc data field.

isotopic space and the shape of the mixing array in Figure 8, also suggest that the displacement of the Izu-Bonin-Mariana arc lavas to the left of the "MORB-OIB array" could be due to the composition of the subducted material and not necessarily due to changes of the $\mathrm{Nd} / \mathrm{Hf}$ ratio during either dehydration or melting of the sediment component. This is consistent with the relationship between Hf isotopic compositions and the $\mathrm{Hf} / \mathrm{Hf}^{*}$ ratios shown in Figure 9a. Wade et al. [2005] showed that by using their estimate of the sediment composition combined with the depleted mantle value recommended by Salters and Stracke [2004], mixing curves did not pass through the Mariana island arc data field (see Figures $9 \mathrm{a}$ and $9 \mathrm{~b}$ ). They suggested that the $\mathrm{Hf} / \mathrm{Hf} *$ ratio of the depleted mantle might be too high, but also that the $\mathrm{Nd} / \mathrm{Hf}$ ratio of the sediment involved in the source of the volcanic rocks had to be much higher than their sediment estimate (see Figure $9 \mathrm{~b}$ and their Figure 8). Using our estimate of the composition of the sediment pile, the discrepancy between mixing proportions given by the isotopic compositions (less than $2 \%$, see Figure 8 ) and by the trace element ratios (less than 4\%, see Figures 9a and $9 b$ ) is lower but still exists. To have similar proportions of sediments in the two figures requires a mantle wedge with a slight $\mathrm{Hf}$ deficiency relative to its REE content. Most of the Izu-Mariana arc lava data points can be explained by mixing of depleted mantle and bulk sediment. Significant outliers are the Izu forearc lavas [Pearce et al., 1999] which have extremely high Hf/Hf* and low $\mathrm{Nd} / \mathrm{Hf}$ ratios and the Kasuga seamounts in the Mariana arc [Tollstrup and Gill, 2005] which have extremely low $\varepsilon_{\mathrm{Hf}}$ and $\mathrm{Hf} / \mathrm{Hf}^{*}$ values and high $\mathrm{Nd} / \mathrm{Hf}$ ratios. These two data sets cannot be explained by any simple mixing relationship and require additional processes to account for their arrays. Pearce et al. [1999] suggested that the elevated Hf/Hf* values of the Izu protoarc lavas require a fractionation process that either added $\mathrm{Hf}$ or removed REE from the lavas while Tollstrup and Gill [2005] argued that residual rutile, zircon, and monazite were necessary to explain the Kasuga seamount array.

[34] Even if the site 1149 sediments have trace element contents and Nd-Hf isotopic compositions suggesting that simple bulk mixing between subducted sediments and mantle wedge could explain the Nd-Hf characteristics of the Izu-Mariana island arc lavas, things are more complex when other isotopic systems are considered. In particular, previous studies done by Elliott et al. [1997], Ishikawa and Tera [1999], Hochstaedter et al. [2001], Hauff et al. [2003], and by Straub et al. [2004] clearly demonstrated that some elements were transferred from the subducted material to the source of volcanics through fluid phases. Fractionation of trace elements like the REE and the HFSE by residual minerals during magma genesis is also required by the composition of both the Izu protoarc volcanics and the Kasuga seamounts in the Mariana arc (see Figures 9a and 9b). 
[35] When site 1149 data are used as the sediment contaminant in the mantle wedge below the Izu arc, the modeling is quite satisfactory but the number of $\mathrm{Nd}-\mathrm{Hf}$ isotopic analyses on the Izu volcanics is so low that the constraints are relatively weak. More analyses of the Izu volcanics would certainly help refine the general model. In the case of the Mariana arc, for which a significant number of Nd-Hf analyses has been published, the composition of the subducted sediment is poorly constrained: the estimate suggested by Wade et al. [2005] for Site 801 has an $\varepsilon_{\mathrm{Hf}}$ and a $\mathrm{Nd} / \mathrm{Hf}$ ratio that are too low to define a mixing array going through the arc data (see Figures 8 and 9). The Site 452 clay composite analyzed by Woodhead [1989] has $\varepsilon_{\mathrm{Hf}}$ and $\varepsilon_{\mathrm{Nd}}$ similar to the Site 1149 average values (Figure 8) but no trace element data have been published. Finally, the Site 1149 sediments have trace element and isotopic compositions defining mixing arrays compatible with the Mariana arc data, but the drill site is not located in front of the Mariana arc, and contains different sedimentary units than found there [Plank et al., 2007]. The main difference between the Site 1149 and Site 801 sedimentary averages are the Cretaceous volcaniclastics that are a major part of the sedimentary input to the Marianas trench. These have isotopic compositions similar to OIB, and their inclusion in the Site 801 average is responsible for the lower $\varepsilon_{\mathrm{Hf}}$ and $\mathrm{Nd} / \mathrm{Hf}$, and the misfits to the mixing lines. One possible solution to the mixing problem is that $\mathrm{Nd}$ and $\mathrm{Hf}$ are retained in the volcaniclastic unit, by the preferential stability of zircon and REE phases expected in these Zr- and REE-enriched materials [Klimm et al., 2008]. Another possibility is simply that more data are necessary to establish whether a geographical variability exists. The average compositions of the subducted sediment pile in front of the Mariana arc and the Izu-Bonin arc could then be compared and a well constrained model could be developed.

[36] In 2003, Straub published an overview of the temporal changes in the chemical composition of the Izu Bonin-Mariana arc lavas [Straub, 2003]. She demonstrated that over the past $50 \mathrm{Ma}$, the lava composition changed from boninitic to tholeiitic with an accompanying increase in $\mathrm{TiO}_{2}$ contents and $\varepsilon_{\mathrm{Nd}}$ values. Because the $\mathrm{Nd}$ isotopic composition of the sedimentary pile is quite uniform at $\varepsilon_{\mathrm{Nd}} \approx-6.5$ (see Table 2 and Figure 4), secular changes in the sediment composition cannot explain the variation observed in the arc lavas. We suggest therefore that the increasingly depleted nature of the arc lavas might relate to a decreasing contribution of the sediment component through time.

\subsection{Recycling of Sediments in Island Arcs and in the Mantle}

\subsubsection{Oceanic Sediments and Worldwide Arc Systems}

[37] In more general terms, the $\mathrm{Nd}$ and $\mathrm{Hf}$ isotopic compositions of oceanic sediments can be compared to the arc lava isotopic array to evaluate their impact on the island arc compositions. In Figure 10, we show a compilation of available data published on island arcs. Not only do the data define an array that is significantly displaced to the left of the MORB-OIB array, but it also has a shallower slope: $\varepsilon_{\mathrm{Hf}}=1.23 . \varepsilon_{\mathrm{Nd}}+6.36$ versus $\varepsilon_{\mathrm{Hf}}=1.59 . \varepsilon_{\mathrm{Nd}}+1.28$. While these values are slightly different from those published by Vervoort et al. [1999] mainly because of new data published within the last 10 years, they confirm the distinctive trend of arc volcanism relative to intraplate volcanism. It can be argued, as is done by Pearce et al. [1999] and by Tollstrup and Gill [2005] that the slope of the "island arc array" results of a decoupling of $\mathrm{Nd}$ and $\mathrm{Hf}$ during dehydration and/or melting of the subducted slab with a sedimentary component characterized by elevated $\mathrm{Nd} / \mathrm{Hf}$ ratios. However, we would like to suggest here that the "island arc array" could also be mainly controlled by the mixing of depleted mantle and subducted sediments. In Figure 10, we show mixing arrays between various sedimentary end-members and an average depleted mantle source. Contaminating the mantle wedge with the Leg 185 average sediment produces an array shown with a black striped line in Figure 10 that goes through the arc data with the highest $\varepsilon_{\mathrm{Hf}}$ values but does not appear to be the best end-member to account for the composition of most island arcs even though it can explain some arcs data (e.g., Izu, Mariana and some of the Luzon arc data). Most arc lavas lie below this mixing line with the arcs located next to continents (the Lesser Antilles and the Aegean arc) defining the lower part of the arc array. We suggest therefore that depending on the nature of the subducted sediments (sands next to continental platforms, and clays, muds and Fe-Mn crusts further away from continental margins) a range of mixing lines can be calculated. In Figure 10, we show two end-member mixing lines calculated using the $\mathrm{Nd}$ and $\mathrm{Hf}$ concentrations and $\mathrm{Nd}$ isotopic composition of GLOSS [Plank and Langmuir, 


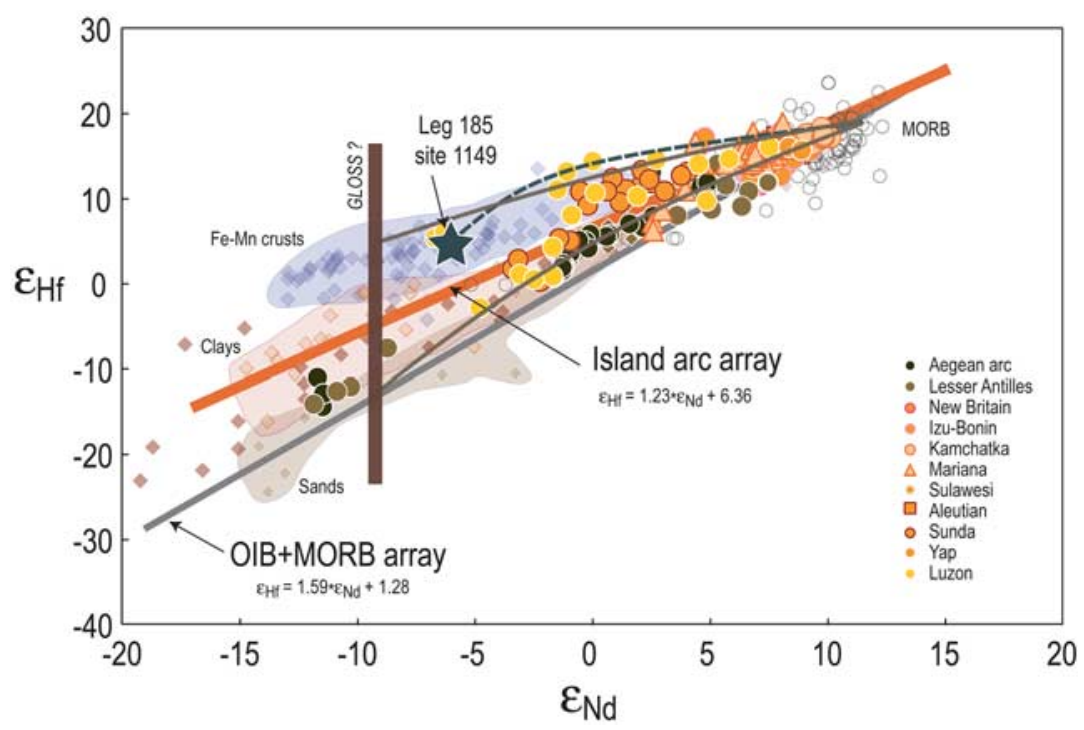

Figure 10. The $\varepsilon_{\mathrm{Hf}}$ versus $\varepsilon_{\mathrm{Nd}}$ diagram showing the relationship between island arc volcanics and oceanic sediments. The island arc array is shown by an orange line while the mantle array is shown by a gray line. Field for the three main types of oceanic sediments are from Chauvel et al. [2008] and data on circum-Antarctic sediments published by van de Flierdt et al. [2007] are also shown (light brown diamonds) but could not be distributed among the fields due to the absence of petrological description. Because no $\varepsilon_{\mathrm{Hf}}$ value is available for GLOSS, its composition is represented by a vertical brown bar at $\varepsilon_{\mathrm{Nd}}=-8.9$. Two typical mixing arrays calculated using the GLOSS $\mathrm{Nd}$ and $\mathrm{Hf}$ concentrations and mantle values as given in the caption of Figure 8 are shown as brown thin curves: one using an elevated $\varepsilon_{\mathrm{Hf}}$ value at about +4 and one using a low $\varepsilon_{\mathrm{Hf}}$ value at -13 . A mixing curve between Site 1149 and depleted mantle is also shown (black dashed curve). Data were compiled using the Georoc database (http://georoc.mpch-mainz.gwdg.de/georoc/) for IAV and OIB and the PetDB database (http://www.petdb.org) for MORB.

1998] for which no Hf isotopic composition is available. We therefore used a range of Hf isotopic compositions as shown by the vertical brown line in Figure 10. The mixing line between depleted mantle and the low $\varepsilon_{\mathrm{Hf}}$ sand end-member reproduces well the Lesser Antilles and Aegean arcs compositions while mixtures of mantle wedge and high $\varepsilon_{\mathrm{Hf}}$ sediments reproduce the compositions of arcs such as Luzon and Sunda. In most cases, the proportion of sediments involved in the source of arc volcanism is lower than $5 \%$ if straight bulk mixing between sediments and mantle is used. If the sediment component is extracted from the sedimentary material by either a fluid phase or a melt, the proportion of sediment will be lower. We realize that this mixing model is quite simplistic and that a better knowledge of the oceanic sediment compositions is really necessary. As mentioned by Plank and van Keken [2008], the diversity of $\varepsilon_{\mathrm{Hf}}, \varepsilon_{\mathrm{Nd}}$, and associated REE/HFSE ratios in oceanic sediments needs to be better documented to understand the way sediments are involved in the arc genesis.

\subsubsection{Proportions of the Incoming Sediment Flux Injected Back Into the Mantle}

[38] Our average composition of the Site 1149 sedimentary pile can be used in conjunction with physical and chemical data to estimate the fraction of subducted sediments that is transferred directly into the arc system, and the fraction that is sent back into the convecting mantle.

[39] The sediment input flux can be evaluated using the convergence rate of the Pacific plate, the thickness of the sediment pile, and its density, water content, and average $\mathrm{Nd}$ and $\mathrm{Hf}$ concentrations. All these values, which are summarized in Table 4, allow estimates of the $\mathrm{Nd}$ input flux from the sediment at $857 \mathrm{~kg} / \mathrm{km}$ of arc/a and of the Hf input rate at $49 \mathrm{~kg} / \mathrm{km}$ of arc/a. The volcanic arc output flux can be evaluated using the magmatic addition rates determined by Dimalanta et al. [2002] for the Izu-Bonin arc and the average $\mathrm{Nd}$ and Hf concentrations of arc lavas [White and Patchett, 1984; Pearce et al., 1999]. Using the 
Table 4. Volcanic Output and Sediment Input Fluxes in the Izu Subduction Zone

\begin{tabular}{|c|c|c|c|}
\hline & Output Flux & Sediment Flux & Mantle Wedge \\
\hline Volume $\left(\times 10^{-6} \mathrm{~km}^{3} / \mathrm{km} / \mathrm{a}\right)$ & $65.5^{\mathrm{a}}$ & $28.6^{\mathrm{b}}$ & \\
\hline Density $\left(\mathrm{g} / \mathrm{cm}^{3}\right)$ & 2.8 & $1.74^{\mathrm{c}}$ & \\
\hline wt $\%$ water & & $31.6^{\mathrm{c}}$ & \\
\hline Total dry flux $\left(\times 10^{9} \mathrm{~kg} / \mathrm{km} / \mathrm{a}\right)$ & 0.183 & 0.03399 & \\
\hline Average $\mathrm{Nd}$ concentration (ppm) & $7.5^{\mathrm{d}}$ & $25.2^{\mathrm{c}}$ & \\
\hline$\varepsilon_{\mathrm{Nd}}$ value & +7 to $+9^{\mathrm{e}}$ & $-5.9^{\mathrm{e}}$ & $+9.7^{\mathrm{f}}$ \\
\hline Nd flux $(\mathrm{kg} / \mathrm{km} / \mathrm{a})$ & 1375 & 857 & \\
\hline Average Hf concentration (ppm) & $1.7^{\mathrm{d}}$ & $1.44^{\mathrm{c}}$ & \\
\hline Hf flux $(\mathrm{kg} / \mathrm{km} / \mathrm{a})$ & 312 & 49 & \\
\hline $\mathrm{Nd} / \mathrm{Hf}$ & 4.41 & 17.5 & \\
\hline
\end{tabular}

${ }^{\mathrm{a}}$ Average value for Izu-Bonin of Dimalanta et al. [2002].

${ }^{\mathrm{b}}$ Calculated with a subduction rate of $7 \mathrm{~cm} / \mathrm{a}$ and a sediment thickness of $410 \mathrm{~m}$.

${ }^{\mathrm{c}}$ Data from Plank et al. [2007].

${ }^{\mathrm{d}}$ Average values of data from White and Patchett [1984] and Pearce et al. [1999].

e Range of values of data from White and Patchett [1984] and Pearce et al. [1999] for the arc lavas.

${ }^{\mathrm{f}}$ Average value of Pacific MORB.

values listed in Table 4, we calculate a $\mathrm{Nd}$ output rate of about $1375 \mathrm{~kg} / \mathrm{km}$ of arc/a and a Hf output rate of about $312 \mathrm{~kg} / \mathrm{km}$ of arc/a. The $\mathrm{Nd}$ and $\mathrm{Hf}$ present in the arc lavas originate most probably from both the mantle wedge and the subducted material. Using the $\varepsilon_{\mathrm{Nd}}$ values given in Table 4 for the average arc lavas, the mantle wedge and the subducted material, we can calculate that about $10 \% \pm 6 \%$ of the $\mathrm{Nd}$ present in the arc lavas comes from the subducted sediment, i.e., $138 \pm 82 \mathrm{~kg} / \mathrm{km}$ of arc/a. Subtracting this amount from the total amount of $\mathrm{Nd}$ present in the subducted sediment pile implies that about $85 \% \pm 9 \%$ of the sedimentary $\mathrm{Nd}$ is sent back into the convecting mantle.

[40] A similar calculation carried out for $\mathrm{Hf}$ does not provide well-constrained proportions because the $\varepsilon_{\mathrm{Hf}}$ values of mantle wedge and arc lava are almost indistinguishable. However, using the $\mathrm{Nd} /$ Hf ratios of the three components, we can place limits to the proportion of $\mathrm{Hf}$ from the sediment pile that is transferred to the arc lavas and the amount that is recycled into the mantle. Assuming that the sedimentary material involved in the arc lava genesis has the same $\mathrm{Nd} / \mathrm{Hf}$ ratio as the sediment itself, we evaluate the Hf flux from sediment to arc lava as $7.9 \mathrm{~kg} / \mathrm{km}$ of arc/a and calculate that $85 \% \pm 9 \%$ of sedimentary $\mathrm{Hf}$ is recycled back into the mantle. It is very unlikely that the $\mathrm{Nd} / \mathrm{Hf}$ of the material coming out of the subducted material is lower than that of the sediment because $\mathrm{Nd}$ is considered as more mobile in fluid phases than Hf [Kogiso et al., 1997; Johnson and Plank, 1999]. Dehydration products are therefore likely to have a $\mathrm{Nd} / \mathrm{Hf} \geq 17.5$ and transfer less than the $7.9 \mathrm{~kg} / \mathrm{km}$ of arc/a calculated above. This in turn suggests that a minimum of $85 \%$ of the sedimentary $\mathrm{Hf}$ is recycled back into the mantle.

[41] In summary, the $\mathrm{Nd}$ and the Hf present in the sedimentary pile contribute to the arc lava composition but the vast majority $(\geq 85 \%)$ is recycled into the mantle of the Earth to affect its general isotopic composition. Assuming that similar material has been recycled into the mantle over long periods of time during Earth history, its composition, which differs significantly from that of normal mantle, can create large chemical and isotopic heterogeneities. As already suggested by previous authors [Hofmann and White, 1982; Chauvel et al., 1992; Blichert-Toft and Albarède, 1999], such material could be present in the source of ocean island basalts. It could also be mixed into the normal depleted mantle and suppress the radiogenic growth of both $\mathrm{Nd}$ and $\mathrm{Hf}$ resulting from magmatic melt extraction of continental crust. Such modeling of the impact of recycled subducted oceanic basalt and sediments into the mantle over Earth history was performed recently by Chauvel et al. [2008] for the $\mathrm{Nd}$ and $\mathrm{Hf}$ isotopic systems and they showed that a combination of oceanic sediments and basalts could satisfactorily contribute to the mantle sources of both oceanic island basalts and mid-ocean ridge basalts and explain the "mantle array."

\section{Conclusion}

[42] Our Hf and Nd isotopic study of the Site 1149 sediments and the Hole $801 \mathrm{C}$ basaltic composites leads to the following main observations: 
[43] 1. The similarity between $\mathrm{Hf}$ and $\mathrm{Nd}$ isotopes measured on the Site $801 \mathrm{C}$ basalts and present-day Pacific MORB suggest that both isotopic systems are unaffected by hydrothermal processes and low temperature alteration for a period of more than $150 \mathrm{Ma}$.

[44] 2. The $\mathrm{Hf}$ and $\mathrm{Nd}$ isotopic compositions of Site 1149 sediments do not display a large range and the average composition of the entire sedimentary pile falls in the field of Fe-Mn crusts and nodules at $\varepsilon_{\mathrm{Nd}}=-5.9$ and $\varepsilon_{\mathrm{Hf}}=+4.4$.

[45] 3. The $\mathrm{Hf}$ and $\mathrm{Nd}$ isotopic composition of the Izu-Mariana arc lavas can be modeled by mixing a Pacific type mantle wedge and less than 2\% sediments and the composition of most island arc lavas can be reproduced by mixing less than $5 \%$ oceanic sediments with an ordinary depleted mantle wedge.

[46] 4. We evaluate that about $85 \%$ of the $\mathrm{Nd}$ present in the subducted sediments is recycled into the mantle. For Hf, the proportion is constrained to be similar $(85 \%)$ or higher. Consequently, most of the $\mathrm{Nd}$ or $\mathrm{Hf}$ present in the oceanic sediments is recycled into the mantle to create chemical heterogeneities and affect its average composition.

\section{Appendix A: Optimization of the Chemical Purification}

[47] The analytical procedure for Hf separation was based on the method published by Blichert-Toft et al. [1997] which proved to be highly efficient for most of the Site 801C composites and Site 1149 sediments but failed for two particular sample groups and had to be modified: (1) The Hf isolation was unsuccessful for cherts and porcelanites collected at Site 1149. For these samples, Hf was not efficiently separated from heavy rare earth elements (HREE), and the Hf isotopic measurements on the P54 were disturbed by isobaric interferences at mass 176 caused by $\mathrm{Yb}$ and $\mathrm{Lu}$. (2) The Hf chemical separation was poorly efficient for $\mathrm{Ca}$ rich samples such as the marl and chalk but also for two basalt composites containing calcareous interpillow sediments. For these samples, the Hf recovery was extremely low and often insufficient for a proper isotopic measurement on the P54.

[48] In the analytical procedure of Blichert-Toft et al. [1997] Hf is separated from the HREE using a HF leaching technique after sample dissolution. The REE precipitate into $\mathrm{Ca}-\mathrm{Mg}$ fluoride salts while Hf remains in solution in the supernatant. For most samples, this procedure allows an almost
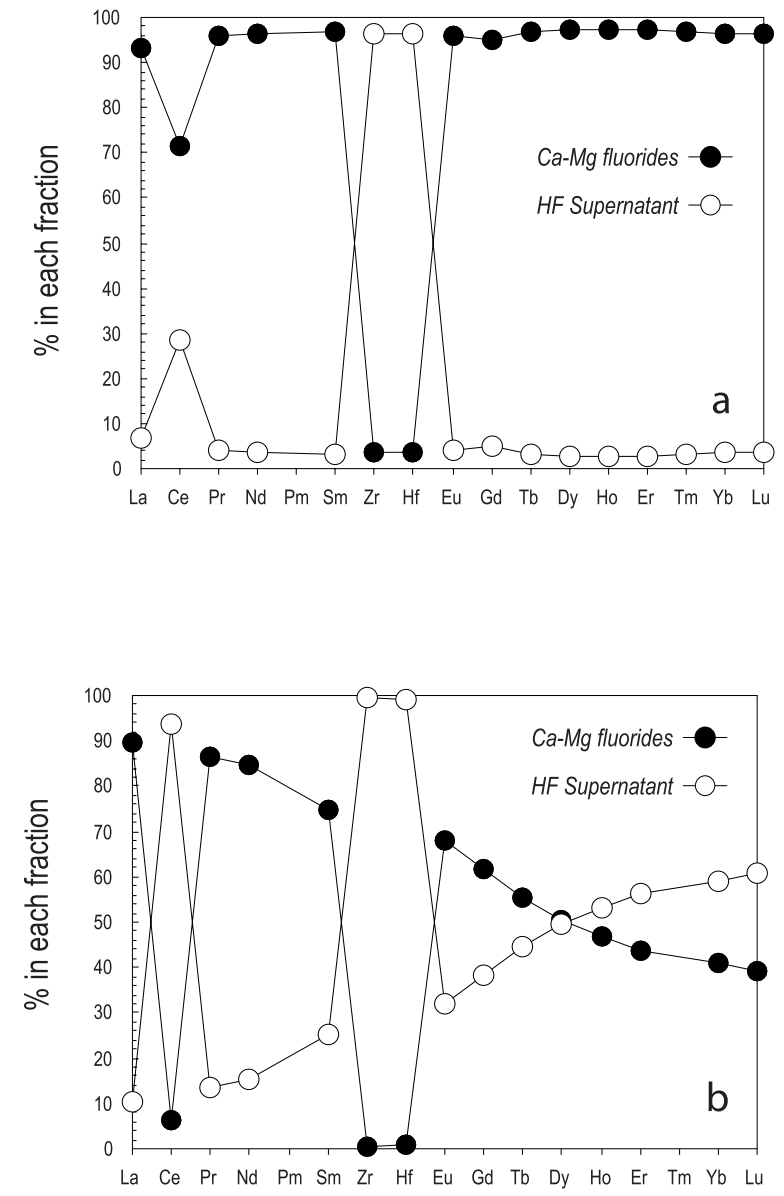

Figure A1. REE, Zr, and Hf distributions between supernatant and fluoride salts after HF leaching of (a) a sample moderately enriched in $\mathrm{Ca}$ and (b) a Ca-depleted sample.

complete recovery of $\mathrm{Hf}$ in the supernatant solution whereas virtually $100 \%$ of the REE are trapped into the Ca-Mg fluoride salts [Blichert-Toft et al., 1997]. However, Blichert-Toft [2001] has shown that this procedure is inadequate to separate $\mathrm{Hf}$ from REE in Mg-rich samples (such as komatiites or picrites) because during the fluoride precipitation stage, $\mathrm{Hf}$ is entrained with the REE leading to low Hf recovery in the supernatant. Blichert-Toft [2001] suggested that the presence of high concentrations of $\mathrm{Hf}$ in the fluorides salts was probably due to high partition coefficients for $\mathrm{Hf}$ in $\mathrm{Mg}$-rich fluorides.

[49] The low Hf recovery we experienced for $\mathrm{Ca}$-rich samples suggests that a similar Hf precipitation occurs during $\mathrm{HF}$ leaching of $\mathrm{Ca}$-rich materials. On the other hand, the very low $\mathrm{Mg}$ and $\mathrm{Ca}$ contents of cherts and porcelanites $(\mathrm{CaO}$ and $\mathrm{MgO}$ usually lower than 1\%) could explain why HREE did not quantitatively precipitate into 
Table A1. Trace Element Distributions After HF Leaching of Ca-Moderately Enriched, Ca-Highly Enriched, and Ca-Depleted Samples

\begin{tabular}{|c|c|c|c|c|c|}
\hline Sample & \multicolumn{2}{|c|}{$80 \mathrm{~J} 102^{\mathrm{a}}$} & $287 C^{b}$ & \multicolumn{2}{|c|}{$\mathrm{PC} \mathrm{B}^{\mathrm{a}}$} \\
\hline Rock Type & \multicolumn{2}{|c|}{ Basalt } & Limestone & \multicolumn{2}{|c|}{ Andesite } \\
\hline Location & \multicolumn{2}{|c|}{ Sunda arc } & SE France & \multicolumn{2}{|c|}{ Sunda arc } \\
\hline $\mathrm{CaO} \%$ & \multicolumn{2}{|c|}{8.38} & 50.61 & \multirow{2}{*}{\multicolumn{2}{|c|}{$\begin{array}{l}0.70 \\
5.24\end{array}$}} \\
\hline $\mathrm{MgO} \%$ & & & 0.60 & & \\
\hline Element $^{\mathrm{c}}$ & Fluoride (\%) & Supernatant (\%) & Supernatant $(\%)$ & Fluoride (\%) & Supernatant (\%) \\
\hline $\mathrm{La}$ & 93.4 & 6.6 & 0 & 89.5 & 10.5 \\
\hline $\mathrm{Ce}$ & 71.5 & 28.5 & 0 & 6.2 & 93.8 \\
\hline $\operatorname{Pr}$ & 95.8 & 4.2 & 0 & 86.5 & 13.5 \\
\hline $\mathrm{Nd}$ & 96.2 & 3.8 & 0 & 84.7 & 15.3 \\
\hline $\mathrm{Sm}$ & 96.8 & 3.2 & 0 & 74.7 & 25.3 \\
\hline $\mathrm{Zr}$ & 3.7 & 96.3 & 0.2 & 0.6 & 99.4 \\
\hline Hf & 3.6 & 96.4 & 0 & 1.0 & 99.0 \\
\hline $\mathrm{Eu}$ & 95.8 & 4.2 & 0.1 & 68.2 & 31.8 \\
\hline $\mathrm{Gd}$ & 94.9 & 5.1 & 0 & 61.9 & 38.1 \\
\hline $\mathrm{Tb}$ & 96.9 & 3.1 & 0 & 55.2 & 44.8 \\
\hline Dy & 97.1 & 2.9 & 0 & 50.5 & 49.5 \\
\hline Ho & 97.1 & 2.9 & 0 & 47.0 & 53.0 \\
\hline $\mathrm{Er}$ & 97.1 & 2.9 & 0 & 43.7 & 56.3 \\
\hline $\mathrm{Yb}$ & 96.3 & 3.7 & 0 & 40.9 & 59.1 \\
\hline $\mathrm{Lu}$ & 96.4 & 3.6 & 0.6 & 39.4 & 60.6 \\
\hline
\end{tabular}

the fluoride salts during the HF leaching procedure. To confirm this interpretation, we performed experiments on the partitioning of $\mathrm{Zr}$, $\mathrm{Hf}$, and REE during HF leaching and fluoride precipitation in Ca-rich and Ca-depleted samples. Three test samples were selected on the basis of their major elements (Table A1): one basalt from the Sunda arc moderately enriched in $\mathrm{CaO}(\mathrm{CaO}=$ $8.38 \%$ ), one limestone from southeast France rich in $\mathrm{CaO}(\mathrm{CaO}=50.61 \%)$, and one andesite from the Sunda arc with a particularly low $\mathrm{CaO}(\mathrm{CaO}=$ $0.7 \%)$. All three samples have low $\mathrm{MgO}(3.8 \%$, $0.6 \%$, and $5.24 \%$, respectively) precluding potential trapping of HFSE in Mg-rich fluorides.

[50] Powders of the three samples were dissolved in savillex beakers with an $\mathrm{HF}: \mathrm{HNO}_{3}$ mixture $(\approx 6: 1)$ at about $140^{\circ} \mathrm{C}$ for $48 \mathrm{~h}$ and residues were leached three times with concentrated HF as recommended by Blichert-Toft et al. [1997]. HF supernatant solutions and $\mathrm{Ca}-\mathrm{Mg}$ fluoride salts were prepared for ICP-MS analysis with the exception of the fluorides formed by the Ca-rich sample because this residue resisted acid digestion and could not be put into solution. Percentages of $\mathrm{REE}, \mathrm{Zr}$, and $\mathrm{Hf}$ recovered in each fraction are given in Table A1 and plotted in Figure A1. For the basalt moderately enriched in $\mathrm{Ca}$, the measured
$\mathrm{REE}$, Hf and $\mathrm{Zr}$ partitioning between $\mathrm{Ca}-\mathrm{Mg}$ fluoride salts and HF supernatant are similar to the results of Blichert-Toft et al. [1997]. More than $97 \%$ of $\mathrm{Zr}$ and $\mathrm{Hf}$ are in the HF supernatant (Figure A1a) while over 95\% of the REE are in the fluoride precipitate. Among the REE, $\mathrm{Ce}$ is an exception with only $71 \%$ in the salt, probably because of the presence of both $\mathrm{Ce}^{3+}$ and $\mathrm{Ce}^{4+}$. As mentioned above, the fluoride salts of the $\mathrm{Ca}$ rich sample could not be analyzed but nevertheless only $2.2 \%$ of $\mathrm{Zr}$ and $0.9 \%$ of $\mathrm{Hf}$ were recovered in the HF supernatant solution (Table A1). This result demonstrates that during HF leaching of Ca-rich material, $\mathrm{Zr}$ and $\mathrm{Hf}$ are partitioned into the fluoride residue instead of staying in solution in HF. This suggests that $\mathrm{Zr}$ and $\mathrm{Hf}$ have significantly higher partition coefficients for Ca-rich fluorides than for Ca-poor fluorides. In contrast to the other two samples, the Ca-depleted andesite shows distinctive features (see Figure $\mathrm{Alb}$ ): $\mathrm{Zr}$ and $\mathrm{Hf}$ are almost exclusively present in the HF supernatant (more than $99 \%$ of $\mathrm{Zr}$ and $\mathrm{Hf}$ ) but the REE are also present in the leachate and show a progressive fractionation with the LREE mainly concentrated in the fluoride salt (over 80\%) and the HREE distributed equally between the residue and the leachate $(59 \%$ of $\mathrm{Yb}$ in the supernatant). Such 
distribution suggests a progressive decrease of the partition coefficient from LREE to HREE in the Ca-depleted fluoride salts and an inefficient separation of the REE from the HFSE using the HF leaching technique in such samples.

[51] Our experiments demonstrate therefore that the $\mathrm{Ca}$ content plays a fundamental role on the distribution of HFSE and REE between fluoride salts and supernatant solution during HF leaching. For moderately Ca-rich matrices, HFSE are preferentially concentrated in the leachate while REE precipitate in the fluorides; for Ca-rich samples, HFSE and REE precipitate together in the fluoride residue; and finally for Ca-depleted samples, HFSE remain in the leachate while REE are evenly distributed between fluoride salts and HF supernatant solution. Despite providing excellent results for most rocks, the HF leaching procedure of Blichert-Toft et al. [1997] proves not to be efficient to separate Hf from REE in Ca-rich and Ca-poor samples and the original protocol of Blichert-Toft et al. [1997] has to be modified for this type of rock samples.

[52] For Ca-rich samples, the HF leaching and fluoride precipitation step should be replaced by a cation-exchange column separation as published by Patchett and Tatsumoto [1981] and modified by Revillon [2000]. However, this modified protocol succeeds only if Ca-rich fluorides salts do not precipitate during dissolution of the sample. These fluorides, very resistant to acid dissolution, are likely to contain large amounts of Hf leading to low Hf recovery. We suggest therefore that dissolution of Ca-rich samples should be achieved either using the procedure recommended by Bizimis et al. [2003] or using concentrated HF associated to large amounts of $\mathrm{HClO}_{4}$ or using lithium metaborate fusion as described by LeFèvre and Pin [2001]. For Ca-depleted samples, the modified procedure consists simply in a column separation using cation-exchange resin instead of Hf leaching. In this case, REE are recovered from the cation-exchange column. In all cases, $\mathrm{Nd}$ is further isolated from the other REE using Eichrom ${ }^{\circledR}$ HDEHP-coated Teflon resin.

\section{Acknowledgments}

[53] This work was financially supported by the French CNRS programs "Intérieur de la Terre" and "Dyeti," and by the U.S. NSF (OCE-0137110). Help in the chemistry lab provided by Francine Keller and on the Lyon MC-ICPMS by Philippe Telouk were highly valuable and discussions with Marion Carpentier, Ivan Vlastelic, and Nicholas Arndt con- tributed to a clearer interpretation of the data. Very constructive comments made by the reviewers (M. Bizimis, I. Savov, and an anonymous reviewer) and the editors J. Ryan and V. Salters helped improve the content and clarity of the discussion.

\section{References}

Albarède, F., A. Simonetti, J. D. Vervoort, J. Blichert-Toft, and W. Abouchami (1998), A Hf-Nd isotopic correlation in ferromanganese nodules, Geophys. Res. Lett., 25(20), 38953898, doi:10.1029/1998GL900008.

Alt, J. C. (2003), Stable isotopic composition of upper oceanic crust formed at a fast spreading ridge, ODP Site 801, Geochem. Geophys. Geosyst., 4(5), 8908, doi:10.1029/ 2002GC000400.

Alt, J. C., C. France-Lanord, P. A. Floyd, P. R. Castillo, and A. Galy (1992), Low-temperature hydrothermal alteration of jurassic ocean crust, Site 801, Proc. Ocean Drill. Program, Sci. Results, 129, 415-427.

Armstrong, R. L. (1968), A model for the evolution of strontium and lead isotopes in a dynamic Earth, Rev. Geophys., 6, 175-199, doi:10.1029/RG006i002p00175.

Armstrong, R. L. (1991), The persistent myth of crustal growth, Aust. J. Earth Sci., 38, 613-630, doi:10.1080/ 08120099108727995.

Barr, S. R., S. Révillon, T. S. Brewer, P. K. Harvey, and J. Tarney (2002), Determining the inputs to the Mariana Subduction Factory: Using core-log integration to reconstruct basement lithology at ODP Hole 801C, Geochem. Geophys. Geosyst., 3(11), 8901, doi:10.1029/2001GC000255.

Bartolini, A. (2003), Cretaceous radiolarian biochronology and carbon isotope stratigraphy of ODP Site 1149 (northwestern Pacific, Nadezhda Basin), Proc. Ocean Drill. Program, Sci. Results, 185, 17.

Bartolini, A., and R. L. Larson (2001), Pacific microplate and the Pangea supercontinent in the Early to Middle Jurassic, Geology, 29(8), 735-738, doi:10.1130/0091-7613(2001) 029<0735:PMATPS $>2.0$.CO;2.

BenOthman, D., W. M. White, and P. J. Patchett (1989), The geochemistry of marine sediments, island arc magma genesis, and crust-mantle recycling, Earth Planet. Sci. Lett., 94 , 1-21, doi:10.1016/0012-821X(89)90079-4.

Bizimis, M., V. M. Salters, and J. B. Dawson (2003), The brevity of carbonatite sources in the mantle: Evidence from Hf isotopes, Contrib. Mineral. Petrol., 145(3), 281-300, doi:10.1007/s00410-003-0452-3.

Blichert-Toft, J. (2001), On the Lu-Hf isotope geochemistry of silicate rocks, Geostand. Newsl., 25(1), 41-56, doi:10.1111/ j.1751-908X.2001.tb00786.x.

Blichert-Toft, J., and F. Albarède (1997), The Lu-Hf isotope geochemistry of chondrites and the evolution of the mantlecrust system, Earth Planet. Sci. Lett., 148, 243-258, doi:10.1016/S0012-821X(97)00040-X.

Blichert-Toft, J., and F. Albarède (1999), Hf isotopic compositions of the Hawaii Scientific Drilling Project core and the source mineralogy of Hawaiian basalts, Geophys. Res. Lett., 26(7), 935-938, doi:10.1029/1999GL900110.

Blichert-Toft, J., C. Chauvel, and F. Albarède (1997), Separation of $\mathrm{Hf}$ and $\mathrm{Lu}$ for high-precision isotope analysis of rock samples by magnetic sector-multiple collector ICP-MS, Contrib. Mineral. Petrol., 127, 248-260, doi:10.1007/s004100050278.

Castillo, P. R., P. A. Floyd, and C. France-Lanord (1992), Isotope geochemistry of Leg 129 basalts: Implications for 
the origin of the widespread cretaceous volcanic event in the Pacific, Proc. Ocean Drill. Program, Sci. Results, 129, 405413.

Chauvel, C., and J. Blichert-Toft (2001), A hafnium isotope and trace element perspective on melting of the depleted mantle, Earth Planet. Sci. Lett., 190, 137-151, doi:10.1016/S0012821X(01)00379-X.

Chauvel, C., A. W. Hofmann, and P. Vidal (1992), HIMU-EM: The French Polynesian connection, Earth Planet. Sci. Lett., 110, 99-119, doi:10.1016/0012-821X(92)90042-T.

Chauvel, C., W. McDonough, G. Guille, R. Maury, and R. Duncan (1997), Contrasting old and young volcanism in Rurutu Island, Austral Chain, Chem. Geol., 139, 125143, doi:10.1016/S0009-2541(97)00029-6.

Chauvel, C., E. Lewin, M. Carpentier, N. T. Arndt, and J.-C. Marini (2008), Role of recycled oceanic basalt and sediment in generating the Hf-Nd mantle array, Nat. Geosci., 1(1), 64-67, doi:10.1038/ngeo.2007.51.

Coffin, M. F., L. A. Lawver, L. M. Cahagan, and D. A. Campbell (2000), The Plates Project 2000 atlas of plate reconstructions (750 Ma to present day), Plates Proj. Progr. Rep., 250, Univ. of Tex., Austin.

David, K., M. Frank, R. K. O’Nions, N. S. Belshaw, and J. W. Arden (2001), The Hf isotope composition of global seawater and the evolution of $\mathrm{Hf}$ isotopes in the deep Pacific Ocean from Fe-Mn crusts, Chem. Geol., 178, 23-42, doi:10.1016/S0009-2541(00)00427-7.

Dimalanta, C., A. Taira, G. P. Yumul Jr., H. Tokuyama, and K. Mochizuki (2002), New rates of western Pacific island arc magmatism from seismic and gravity data, Earth Planet. Sci. Lett., 202, 105-115, doi:10.1016/S0012-821X(02)00761-6.

Elliott, T., T. Plank, A. Zindler, W. M. White, and B. Bourdon (1997), Element transport from slab to volcanic front at the Mariana arc, J. Geophys. Res., 102(B7), 14,991-15,019, doi:10.1029/97JB00788.

Fisk, M., and K. A. Kelley (2002), Probing the Pacific's oldest MORB glass: Mantle chemistry and melting conditions during the birth of the Pacific Plate, Earth Planet. Sci. Lett., 202, 741-752, doi:10.1016/S0012-821X(02)00760-4.

Floyd, P. A., and P. R. Castillo (1992), Geochemistry and petrogenesis of jurassic ocean crust basalts, Site 801, Proc. Ocean Drill. Program, Sci. Results, 129, 361-388.

Floyd, P. A., J. A. Winchester, and P. R. Castillo (1992), Geochemistry and petrography of cretaceous sills and lava flows, Sites 800 and 802, Proc. Ocean Drill. Program, Sci. Results, 129, 345-359.

Fryer, P., B. Taylor, C. H. Langmuir, and A. G. Hochstaedter (1990), Petrology and geochemistry of lavas from the Sumisu and Torishima backarc rifts, Earth Planet. Sci. Lett., 100, 161-178, doi:10.1016/0012-821X(90)90183-X.

Godfrey, L. V., D.-C. Lee, W. F. Sangrey, A. N. Halliday, V. J. M. Salters, J. R. Hein, and W. M. White (1997), The Hf isotopic composition of ferromanganese nodules and crusts and hydrothermal manganese deposits: Implications for seawater Hf, Earth Planet. Sci. Lett., 151, 91-105, doi:10.1016/ S0012-821X(97)00106-4.

Hauff, F., K. Hoernle, and A. Schmidt (2003), Sr-Nd-Pb composition of Mesozoic Pacific oceanic crust (Site 1149 and 801, ODP Leg 185), Implications for alteration of ocean crust and the input into the Izu-Bonin-Mariana subduction system, Geochem. Geophys. Geosyst., 4(8), 8913, doi:10.1029/2002GC000421.

Hickey-Vargas, R. (1998), Origin of the Indian Ocean-type isotopic signature in basalts from Philippine Sea plate spreading centers: An assessment of local versus large-scale processes, J. Geophys. Res., 103(B9), 20,963-20,979, doi:10.1029/98JB02052.

Hochstaedter, A. G., J. B. Gill, M. Kusakabe, S. Newman, M. S. Pringle, B. Taylor, and P. Fryer (1990a), Volcanism in the Sumisu Rift, I. Major element, volatile, and stable isotope geochemistry, Earth Planet. Sci. Lett., 100, 179194, doi:10.1016/0012-821X(90)90184-Y.

Hochstaedter, A. G., J. B. Gill, and J. D. Morris (1990b), Volcanism in the Sumisu Rift, II. Subduction and non-subduction related components, Earth Planet. Sci. Lett., 100, 195-209, doi:10.1016/0012-821X(90)90185-Z.

Hochstaedter, A. G., J. B. Gill, B. Taylor, O. Ishizuka, M. Yuasa, and S. Morita (2000), Across-arc geochemical trends in the Izu-Bonin arc: Constraints on source composition and mantle melting, J. Geophys. Res., 105(B1), 495-512, doi:10.1029/ 1999JB900125.

Hochstaedter, A. G., J. B. Gill, R. Peters, P. Broughton, P. Holden, and B. Taylor (2001), Across-arc geochemical trends in the Izu-Bonin arc: Contributions from the subducting slab, Geochem. Geophys. Geosyst., 2(7), 1019, doi:10.1029/2000GC000105.

Hofmann, A. W. (1988), Chemical differentiation of the Earth: The relationship between mantle, continental crust, and oceanic crust, Earth Planet. Sci. Lett., 90, 297-314, doi:10.1016/ 0012-821X(88)90132-X.

Hofmann, A. W., and W. M. White (1982), Mantle plumes from ancient oceanic crust, Earth Planet. Sci. Lett., 57, 421-436, doi:10.1016/0012-821X(82)90161-3.

Hussong, D. M., et al. (1982), Site 452: Mesozoic Pacific Ocean basin, Initial Rep. Deep Sea Drill. Proj., 60, 77-93.

Ikeda, Y., and M. Yuasa (1989), Volcanism in nascent back-arc basins behind the Shichito Ridge and adjacent areas in the Izu-Ogasawara arc, northwest Pacific: Evidence for mixing between E-type MORB and island arc magmas at the initiation of back-arc rifting, Contrib. Mineral. Petrol., 101, $377-$ 393, doi:10.1007/BF00372212.

Ishikawa, T., and F. Tera (1999), Two isotopically distinct fluid components involved in the Mariana arc: Evidence from $\mathrm{Nb} / \mathrm{B}$ ratios and $\mathrm{B}, \mathrm{Sr}, \mathrm{Nd}$, and $\mathrm{Pb}$ isotope systematics, Geology, 27(1), 83-86, doi:10.1130/0091-7613(1999)027 $<0083$ :TIDFCI $>2.3 . \mathrm{CO} ; 2$.

Johnson, M. C., and T. Plank (1999), Dehydration and melting experiments constrain the fate of subducted sediments, Geochem. Geophys. Geosyst., 1(12), 1007, doi:10.1029/ 1999GC000014.

Kelley, K. A., T. Plank, J. Ludden, and H. Staudigel (2003), Composition of altered oceanic crust at ODP Sites 801 and 1149, Geochem. Geophys. Geosyst., 4(6), 8910, doi:10.1029/ 2002GC000435.

Klimm, K., J. D. Blundy, and T. H. Green (2008), Trace element partitioning and accessory phase saturation during $\mathrm{H}_{2} \mathrm{O}$-saturated melting of basalt with implications for subduction zone chemical fluxes, J. Petrol., 49(3), 523-553, doi:10.1093/petrology/egn001.

Kogiso, T., Y. Tatsumi, and S. Nakano (1997), Trace element transport during dehydration processes in the subducted oceanic crust: 1. Experiments and implications for the origin of ocean island basalts, Earth Planet. Sci. Lett., 148, $193-$ 205, doi:10.1016/S0012-821X(97)00018-6.

Koppers, A. A. P., H. Staudigel, and R. A. Duncan (2003a), High-resolution ${ }^{40} \mathrm{Ar} /{ }^{39} \mathrm{Ar}$ dating of the oldest oceanic basement basalts in the western Pacific basin, Geochem. Geophys. Geosyst., 4(11), 8914, doi:10.1029/2003GC000574.

Koppers, A. A. P., H. Staudigel, M. S. Pringle, and J. R. Wijbrans (2003b), Short-lived and discontinuous intraplate volcanism in the South Pacific: Hot spots or extensional 
volcanism?, Geochem. Geophys. Geosyst., 4(10), 1089, doi:10.1029/2003GC000533.

Lancelot, Y., et al. (1990), Proceedings of the Ocean Drilling Program, Initial Reports, vol. 129, 488 pp., Ocean Drilling Program, College Station, Tex.

Langmuir, C. H., R. D. Vocke, G. N. Hanson, and S. R. Hart (1978), A general mixing equation with applications to icelandic basalts, Earth Planet. Sci. Lett., 37, 380-392, doi:10.1016/0012-821X(78)90053-5.

Lassiter, J. C., J. Blichert-toft, E. H. Hauri, and H. G. Barczus (2003), Isotope and trace element variations in lavas from Raivavae and Rapa, Cook-Austral Islands: Constraints on the nature of Himu-and EM-mantle and the origin of midplate volcanism in French Polynesia, Chem. Geol., 202, 115-138, doi:10.1016/j.chemgeo.2003.08.002.

Lees, G. J., G. Rowbotham, and P. A. Floyd (1992), Petrography and Geochemistry of graded volcaniclastic sediments and their clasts, Leg 129, Proc. Ocean Drill. Program, Sci. Results, 129, 137-152.

LeFèvre, B., and C. Pin (2001), An extraction chromatography method for Hf separation prior to isotopic analysis using multiple collection ICP-Mass spectrometry, Anal. Chem., 73(11), 2453-2460, doi:10.1021/ac001237g.

Ludden, J. N., T. Plank, R. Larson, and C. Escutia (2006), Leg 185 Synthesis: Sampling the oldest crust in the ocean basins to understand Earth's geodynamic and geochemical fluxes, Proc. Ocean Drill. Program, Sci. Results, 185, 1-35.

McLennan, S. M., S. R. Taylor, M. T. M. Culloch, and J. B. Maynard (1990), Geochemical and Nd-Sr isotopic composition of deep-sea turbidites: Crustal evolution and plate tectonic associations, Geochim. Cosmochim. Acta, 54, 20152050, doi:10.1016/0016-7037(90)90269-Q.

Notsu, K., N. Isshiki, and M. Hirano (1983), Comprehensive strontium isotope study of Quarternary volcanic rocks from the Izu-Ogasawara arc, Geochem. J., 17, 289-302.

Patchett, P. J., and M. Tatsumoto (1981), A routine highprecision method for Lu-Hf isotope geochemistry and chronology, Contrib. Mineral. Petrol., 75, 263-267, doi:10.1007/BF01166766.

Pearce, J. A., P. D. Kempton, G. M. Nowell, and S. R. Noble (1999), Hf-Nd element and isotope perspective on the nature and provenance of mantle and subduction components in Western Pacific arc-basin systems, J. Petrol., 40(11), 1579-1611, doi:10.1093/petrology/40.11.1579.

Pfänder, J. A., C. Münker, A. Stracke, and K. Mezger (2007), $\mathrm{Nb} / \mathrm{Ta}$ and $\mathrm{Zr} / \mathrm{Hf}$ in ocean island basalts - Implications for crust-mantle differentiation and the fate of Niobium, Earth Planet. Sci. Lett., 254, 158-172, doi:10.1016/j.epsl.2006. 11.027.

Piepgras, D. J., and S. B. Jacobsen (1988), The isotopic composition of neodymium in the North Pacific, Geochim. Cosmochim. Acta, 52, 1373-1381, doi:10.1016/00167037(88)90208-6.

Plank, T., and C. H. Langmuir (1998), The chemical composition of subducting sediment and its consequences for the crust and mantle, Chem. Geol., 145, 325-394, doi:10.1016/S0009-2541(97)00150-2.

Plank, T., and P. E. van Keken (2008), The ups and downs of sediments, Nat. Geosci., 1(1), 17-18, doi:10.1038/ ngeo.2007.68.

Plank, T., et al. (2000), Proceedings of the Ocean Drilling Program, Initial Reports, vol. 185, Ocean Drilling Program, College Station, Tex.

Plank, T., K. A. Kelley, R. W. Murray, and L. Q. Stern (2007), Chemical composition of sediments subducting at the Izu-
Bonin trench, Geochem. Geophys. Geosyst., 8(4), Q04I16, doi:10.1029/2006GC001444.

Pringle, M. S. (1992), Radiometric ages of basaltic basement recovered at Sites 800, 801, and 802, Leg 129, Western Pacific Ocean, Proc. Ocean Drill. Program, Sci. Results, 129, 389-404.

Reisberg, L., O. Rouxel, J. Ludden, H. Staudigel, and C. Zimmermann (2008), Re-Os results form ODP Site 801: Evidence for extensive Re uptake during alteration of oceanic crust, Chem. Geol., 248, 256-271, doi:10.1016/j.chemgeo.2007.07.013.

Revillon, S. (2000), Origine et composition du Plateau Océanique Caraïbe, Mem. Geosci. Rennes, 97, 358 pp.

Ryan, J. G., and C. H. Langmuir (1988), Beryllium systematics in young volcanic rocks: Implications for $10 \mathrm{Be}$, Geochim. Cosmochim. Acta, 52(1), 237-244, doi:10.1016/00167037(88)90073-7.

Salters, V. J. M., and A. Stracke (2004), Composition of the depleted mantle, Geochem. Geophys. Geosyst., 5, Q05B07, doi:10.1029/2003GC000597.

Savov, I. P., R. Hickey-Vargas, M. D'Antonio, J. G. Ryan, and P. Spadea (2006), Petrology and geochemistry of West Philippine Basin basalts and early Palau-Kyushu arc volcanic clasts from ODP Leg 195, Site 1201D: Implications for the early history of the Izu-Bonin-Mariana arc, J. Petrol., 47(2), 277-299, doi:10.1093/petrology/egi075.

Schmidt, A. (2001), Temporal and spatial evolution of the Izu island arc, Japan, in terms of Sr-Nd-Pb isotope geochemistry, Ph.D. thesis, 81 pp., Univ. of Kiel, Germany.

Shimizu, H., K. Tachikawa, A. Masuda, and Y. Nozaki (1994), Cerium and neodymium isotope ratios and REE patterns in seawater from the North Pacific Ocean, Geochim. Cosmochim. Acta, 58, 323-333, doi:10.1016/0016-7037(94) 90467-7.

Staudigel, H., K.-H. Park, M. S. Pringle, J. L. Rubenstone, W. H. F. Smith, and A. Zindler (1991), The longevity of the South Pacific isotopic and thermal anomaly, Earth Planet. Sci. Lett., 102, 24-44, doi:10.1016/0012-821X(91) 90015-A.

Staudigel, H., G. R. Davies, S. R. Hart, K. M. Marchant, and B. M. Smith (1995), Large scale isotopic Sr, Nd and O isotopic anatomy of altered oceanic crust: DSDP/ODP sites 417/418, Earth Planet. Sci. Lett., 130, 169-185, doi:10.1016/0012-821X(94)00263-X.

Stern, R., E. Kohut, S. Bloomer, M. Leybourne, M. Fouch, and J. Vervoort (2006), Subduction factory processes beneath the Guguan cross-chain, Mariana Arc: No role for sediments, are serpentinites important?, Contrib. Mineral. Petrol., 151(2), 202-221, doi:10.1007/s00410-005-0055-2.

Straub, S. M. (2003), The evolution of the Izu Bomin-Mariana volcanic arcs (NW Pacific) in terms of major element chemistry, Geochem. Geophys. Geosyst., 4(2), 1018, doi:10.1029/ $2002 \mathrm{GC} 000357$

Straub, S. M., and G. D. Layne (2002), The systematics of boron isotopes in Izu arc front volcanic rocks, Earth Planet. Sci. Lett., 198, 25-39, doi:10.1016/S0012-821X(02)00517-4.

Straub, S. M., G. D. Layne, A. Schmidt, and C. H. Langmuir (2004), Volcanic glasses at the Izu arc volcanic front: New perspectives on fluid and sediment melt recycling in subduction zones, Geochem. Geophys. Geosyst., 5, Q01007, doi:10.1029/2002GC000408

Talbi, E. H., and J. Honnorez (2003), Low-temperature alteration of mesozoic oceanic crust, Ocean Drilling Program Leg 185, Geochem. Geophys. Geosyst., 4(5), 8906, doi:10.1029/ $2002 \mathrm{GC} 000405$. 
Tatsumi, Y., M. Murasaki, and S. Nohda (1992), Across-arc variation of lava chemistry in the Izu-Bonin arc: Identification of subduction components, J. Volcanol. Geotherm. Res., 49, 179-190, doi:10.1016/0377-0273(92)90013-4.

Taylor, R. N., and R. W. Nesbitt (1998), Isotopic characteristics of subduction fluids in an intra-oceanic setting, Izu-Bonin arc, Japan, Earth Planet. Sci. Lett., 164, 79-98, doi:10.1016/ S0012-821X(98)00182-4.

Tera, F., L. Brown, J. Morris, I. S. Sacks, J. Klein, and R. Middleton (1986), Sediment incorporation in island-arc magmas: Inferences from 10Be, Geochim. Cosmochim. Acta, 50(4), 535-550, doi:10.1016/0016-7037(86)90103-1.

Tollstrup, D. L., and J. B. Gill (2005), Hafnium systematics of the Mariana arc: Evidence for sediment melt and residual phases, Geology, 33(9), 737-740, doi:10.1130/G21639.1.

van de Flierdt, T., S. L. Goldstein, S. R. Hemming, M. Roy, M. Frank, and A. N. Halliday (2007), Global neodymiumhafnium isotope systematics-revisited, Earth Planet. Sci. Lett., 259(3-4), 432, doi:10.1016/j.eps1.2007.05.003.

Vervoort, J. D., P. J. Patchett, J. Blichert-Toft, and F. Albarède (1999), Relationships between Lu-Hf and Sm-Nd isotopic systems in the global sedimentary system, Earth Planet. Sci. Lett., 168, 79-99, doi:10.1016/S0012-821X(99)00047-3.

Vlastelic, I., M. Carpentier, and E. Lewin (2005), Miocene climate change recorded in the chemical and isotopic $(\mathrm{Pb}$, $\mathrm{Nd}$, Hf) signature of Southern Ocean sediments, Geochem. Geophys. Geosyst., 6, Q03003, doi:10.1029/2004GC000819.
VonHuene, R., and D. W. Scholl (1991), Observations at convergent margins concerning sediment subduction, subduction erosion, and the growth of continental crust, Rev. Geophys., 29, 279-316, doi:10.1029/91RG00969.

VonHuene, R., and D. W. Scholl (1993), The return of sialic material to the mantle indicated by terrigenous material subducted at convergent margins, Tectonophysics, 219, 163175, doi:10.1016/0040-1951(93)90294-T.

Wade, J. A., et al. (2005), The May 2003 eruption of Anatahan volcano, Mariana Islands: Geochemical evolution of a silicic island-arc volcano, J. Volcanol. Geotherm. Res., 146, 139170, doi:10.1016/j.jvolgeores.2004.11.035.

White, W. M., and P. J. Patchett (1984), Hf-Nd-Sr isotopes and incompatible element abundances in island arcs: Implications for magma origins and crust-mantle evolution, Earth Planet. Sci. Lett., 67, 167-185, doi:10.1016/0012-821X (84)90112-2.

White, W. M., P. J. Patchett, and D. B. Othman (1986), Hf isotope ratios of marine sediments and Mn nodules: Evidence for a mantle source of Hf in seawater, Earth Planet. Sci. Lett., 79, 46-54, doi:10.1016/0012-821X(86)90039-7.

Woodhead, J. D. (1989), Geochemistry of the Mariana arc (western Pacific): Source composition and processes, Chem. Geol., 76, 1-24, doi:10.1016/0009-2541(89)90124-1.

Woodhead, J. D., J. M. Hergt, J. P. Davidson, and S. M. Eggins (2001), Hafnium isotope evidence for 'conservative' element mobility during subduction zone processes, Earth Planet. Sci. Lett., 192, 331-346, doi:10.1016/S0012-821X(01)00453-8. 